\title{
WestVirginiaUniversity
}

THE RESEARCH REPOSITORY @ WVU

Graduate Theses, Dissertations, and Problem Reports

2009

\section{Three essays on resources, institutions, and development across U.S. states}

Joab N. Corey

West Virginia University

Follow this and additional works at: https://researchrepository.wvu.edu/etd

\section{Recommended Citation}

Corey, Joab N., "Three essays on resources, institutions, and development across U.S. states" (2009). Graduate Theses, Dissertations, and Problem Reports. 2833.

https://researchrepository.wvu.edu/etd/2833

This Dissertation is protected by copyright and/or related rights. It has been brought to you by the The Research Repository @ WVU with permission from the rights-holder(s). You are free to use this Dissertation in any way that is permitted by the copyright and related rights legislation that applies to your use. For other uses you must obtain permission from the rights-holder(s) directly, unless additional rights are indicated by a Creative Commons license in the record and/ or on the work itself. This Dissertation has been accepted for inclusion in WVU Graduate Theses, Dissertations, and Problem Reports collection by an authorized administrator of The Research Repository @ WVU.

For more information, please contact researchrepository@mail.wvu.edu. 
Three Essays on Resources, Institutions, and Development across U.S. States

\section{Joab N. Corey}

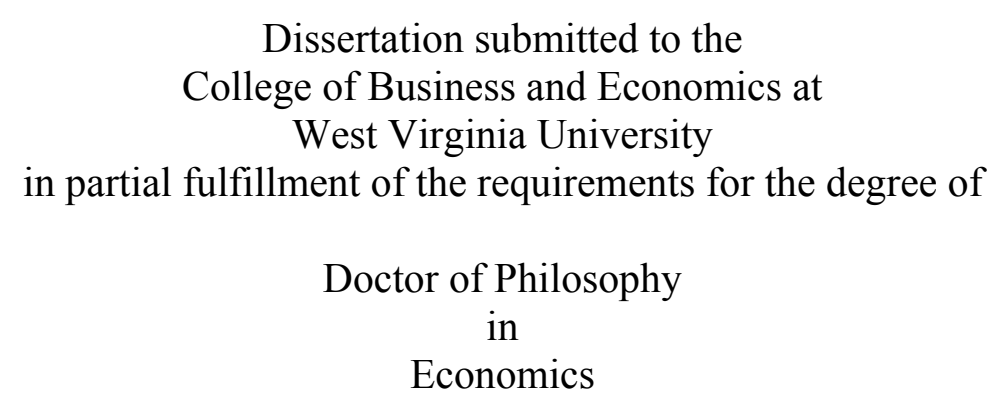
Russell S. Sobel, Ph.D., Chair Chris Coyne, Ph.D.
Tami Gurley-Calvez, Ph.D.
Peter Leeson, Ph.D.
Santiago Pinto, Ph.D.
Department of Economics
Morgantown, West Virginia
2009

Keywords: resource curse, point resources, diffuse resources, institutions, economic freedom, rent-seeking 


\section{ABSTRACT \\ Three Essays on Resources, Institutions, and Development across U.S. States}

Joab N. Corey

This dissertation is a collection of papers examining the relationship between resource intensity, institutional quality, and economic development across the United States. The first chapter introduces the empirical connection between high levels of resource abundance and low levels of economic development known as the resource curse. It then proceeds to briefly introduce the three papers that make up the next three chapters of the dissertation. Chapter two examines the formation of low-quality institutions in areas with a large amount of natural resources. It begins by providing a theoretical model to show that governments will execute more expropriative tax policies in areas with a high level of immobile natural resources. The chapter then examines the state constitution of Wyoming, an incredibly resource intense state with prior knowledge of these resources before the formation of their state government, to find that this constitution is consistent with that of a low quality institution that could hinder economic development. This chapter also provides a simple econometric model to show that governments will form more quickly in high-resource areas where there is a greater level of wealth to expropriate. Chapter 3 examines the link between natural resource abundance and the size of governments. Large governments tend to be consistent with high levels of rentseeking and unproductive entrepreneurship that can hurt economic development. This chapter finds that resource intense states have larger and more economically intrusive governments across several specifications and measures for government size. Chapter four looks at the interaction between low quality institutions, resource abundance, and economic development. This study finds that natural resource endowment only hurts growth in those states with poor institutions, while it can actually enhance growth in those states with productive institutions. Chapter five concludes and discusses areas of future research. 


\section{Acknowledgments}

I would like to thank my dissertation chair, Dr. Russell S. Sobel, whose lectures, help, and enthusiasm inspired me to become an economics educator. I would also like to thank the members of my dissertation committee Dr. Chris Coyne, Dr. Tami Gurley-Calvez, Dr. Peter Leeson, and Dr. Santiago Pinto for their help and advice throughout this entire process

I would also like to thank the faculty, staff, and fellow graduate students in the economics department at West Virginia University for all of their help and support throughout my graduate school career.

Finally, I would like to thank all of the family, friends, instructors, philosophers, authors, and artists whom I have been lucky enough to have impact my life. 


\section{Table of Contents}

Abstract........................................................ ii

Acknowledgements........................................... iii

Table of Contents................................................ iv

List of Tables and Figures....................................... vi

Chapter 1: Resources, Institutions, and Economic Development

1.1 Introduction.................................................. 1

1.2 The Resource Curse Evidence From U.S. State Constitutional Structures................................................. 4

1.3 The Impact of Resource Abundance on the Size of Government....... 6

1.4 The Resource Curse: Institutions, Economic Freedom, and Growth Across U.S. States.......................................... 7

Chapter 2: The Resource Curse: Evidence from U.S. State Constitutional Structures........................................................ $\quad 10$

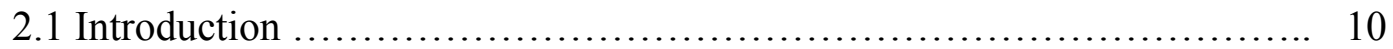

2.2 A Model of Expropriation......................................... 15

2.3 State Constitutional Analysis: The Case of Wyoming................... 16

2.3 .1 Taxation................................................. 18

2.3.2 Regulation................................................ 19

2.3.3: Other Areas of Rent Extraction: Railroads and Water............. 23

2.3.4: Summarizing the Evidence from Wyoming's Constitution......... 25

2.4 The Rise of Governments........................................ 26

2.5 Conclusion.................................................. 29

Chapter 3: The Impact of Resource Abundance on the Size of Government.. 31

3.1 Introduction ..................................................... 31

3.2 Economic Freedom leads to higher growth......................... 32

3.3 The Resource Curse.............................................. 35

3.4 Data.......................................................... 40

3.5 Empirical Model and Results........................................... 46

3.6 Robustness..................................................... 50

3.7 Conclusion.................................................... 60

Chapter 4: The Institutional Curse: Resources, Economic Freedom, and Growth across U.S. States.......................................... 61

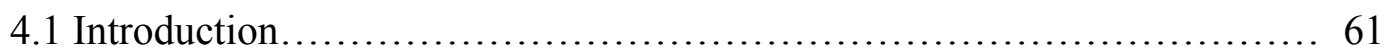

4.2 Economic Freedom and Growth.................................... 63

4.3 Resource Abundance and Growth.................................... 66

4.4 The Resource Curse in the United States............................. 71 


\section{Table of Contents}

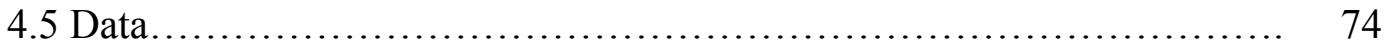

4.6 Empirical Model and Results.................................... 80

4.7 Conclusion................................................. 89

Chapter 5: Conclusion and Areas of Future Research.................. 91

Appendix ....................................................... 95

References........................................................ 100 


\section{List of Tables and Figures}

\section{Tables:}

Table 2.1: Formation of Governments and Resource Abundance............... 28

Table 3.1: Delaware vs. Alaska....................................... 46

Table 3.2: Resource Intensity Average from 1986-1990.................... 49

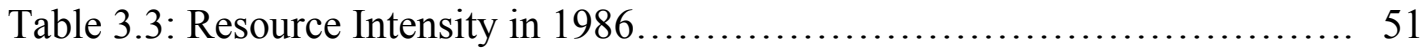

Table 3.4: Share of Republicans in Senate as Political Variable................. 52

Table 3.5: Republican Governor as Political Variable.......................... 54

Table 3.6: Area 1A - Government General Consumption Expenditures as a Percentage of GDP ............................................. 56

Table 3.7: State Government Employees..................................... 58

Table 3.8: State and Local Government Employees............................ 59

Table 4.1: Resource Intensity........................................ 81

Table 4.2: Point Resources............................................ 86

Table 4.3: Diffuse Resources.......................................... 88

Figures:

Figure 1.1: Resource Abundance and Growth across U.S. States................. 11 


\section{Chapter 1}

\section{Resources, Institutions, and Economic Development}

\subsection{Introduction}

The inverse relationship between natural resource abundance and economic development is now referred to as the resource curse. This correlation was first examined at the international level with the seminal work of Sachs and Warner $(1995 ; 2001)$. Since this seemingly paradoxical relationship was first discovered, there has been an extensive effort to find what drives this inverse connection across countries. Sachs and Warner (2001) generalize these explanations by saying that resources crowd out factors that are important for growth and since there is debate about what causes growth, there is debate about what causes the resource curse.

Several studies have concluded that there is an institutional channel through which the resource curse operates. One such explanation is that resource abundance causes the population to have greater expectations regarding growth and development, which increases the pressure placed on the government causing them to make hasty and overly-intrusive policies that will have negative ramifications on the economy (Stevens, 2005). For example, natural resource abundance may cause the government to channel investments away from other profitable growth-enhancing sectors, engage in poor industrial policy, and establish transfers and subsidies while restricting free trade. Additionally, resource abundance has been shown to lead to poor institutional quality and, thus, lower economic growth through the channels of increased corruption and rentseeking. This result was supported by Isham, Woocock, Pritchett, and Busby (2005) who found that rent-seeking and corruption was more greatly affected by immobile point 
resources, which are minerals and fuels that must be mined from the ground, than by diffuse resources such as agriculture which can be moved in response to lower institutional quality. Bulte, Damania, and Deacon (2005), also concluded that point resources are more likely to adversely affect the economy through the indirect channel of institutional quality. Mehlum, Moene, and Torvik (2006) also examined the effect of the interaction between institutional quality and resource abundance on economic development and found that the resource curse only exists in those economies with poor institutions.

Much of the research conducted on the resource curse thus far has been focused at the international level. Only recently has the analysis of the resource curse turned to the sub-national level by focusing on the United States. This is somewhat surprising as the United States provides a fertile ground for the examination of the effects of resource abundance since states are endowed with different levels of natural resource abundance, are governed by different state institutions, and have different levels of economic growth. Further, U.S. data is not subject to as many problems as international data. All states use the same currency so the effect of natural resource abundance on terms of trade (commonly know as Dutch Disease) can be eliminated as a possible explanation. States also have more similar cultures and military history as compared to different countries and this can help eliminate these variables, which are otherwise difficult to measure, as a potential explanation. Finally, U.S. data is more consistent in that the same variables are measured in the same way across the same time period, whereas international data is more subject to inaccurate, inconsistent, or unavailable records. 
Papyrakis and Gerlaugh (2006) provided the first examination of the resource curse across the United States by analyzing the indirect transmission channels of resource abundance. They found that resource abundance leads to lower levels of investment, schooling, openness, and research and development, while increasing corruption. Dunn (2008) begins to examine the institutional connection by providing both theoretical and empirical support that resource abundance will lead to higher levels of rent-seeking through the use of the severance tax across U.S. States. The idea that increased rentseeking can crowd out productive activity and, thus, negatively impact growth is consistent with Baumol's theory of productive and unproductive entrepreneurship (Baumol, 1990). This dissertation further extends the analysis of the institutional connection between resource abundance and low economic development across U.S. States.

The second chapter of this dissertation examines the formation of governments in areas of resource abundance by analyzing the constitution of the state of Wyoming, which was aware of its resource abundance at the time in which it formed its constitution and subsequent state government. This chapter also includes a simple empirical model, which shows that governments formed more quickly in those areas with a known abundance of natural resource wealth available to expropriate. The third chapter uses an empirical model to show that those state with a greater amount of natural resources have more intrusive governments consistent with more unproductive entrepreneurship as exhibited by a lower score in the area of the Economic Freedom of North America Index which measures government size and transfers and subsidies (Karabgovic et al., 2008). This result is mostly driven by the effect of point resources that are immobile, and thus, 
more susceptible to government expropriation. The fourth chapter of this dissertation examines the interaction of resource abundance with institutional quality to conclude that the resource curse only exists in those states with poor institutions, while those states with a considerable amount of natural resources and a high level of institutional quality exhibit higher levels of economic growth. Chapter 5 summarizes the results of the previous chapters and offers some concluding remarks.

\subsection{The Resource Curse: Evidence From U.S. State Constitutional Structures}

This chapter of my dissertation analyzes the rise of governments in areas with greater natural resource abundance. It focuses on the constitution of Wyoming who began extracting minerals from the ground before forming its constitution and state government. This constitutional analysis focuses on three main areas: taxation, regulation, and private property rights. If the hypothesis that more expropriative governments form in order to take advantage of an abundance of natural resources is true, then we would expect to see statements within this constitution consistent with the taxation of these resources as well as regulations focused on the resource sector and other related industries. Also, more liberal eminent domain policies consistent with insecure private property rights are to be expected.

Indeed, contained within Wyoming's Constitution are statements specifically concerned with the taxation of natural resources. Specifically, Wyoming adopted a severance tax so that the government can gain additional revenue from the extraction of natural resources. Also contained within this constitution are extensive regulations with regards to the natural resource sector. This involves regulations on the mines as well as 
labor regulations involving the workers in these industries. Particularly notable are the regulations involving the railroad industry, which is a critical component in the extraction and transportation of natural resources. Lastly, this constitution has eminent domain policies that allow the government to take the land of others, despite their objections. Such policies reduce the incentive for innovation and the ability to profit from the use of the land since it can be taken from you against your will.

This chapter continues its analysis on the rise of governments by looking to see if state governments formed faster in areas with more natural resources. There is a great deal of literature concerning the formation of governments that says that governments will form more quickly in those areas where there is more wealth for the taking. This would include those areas with a greater abundance of natural resources. In order to accurately analyze this hypothesis, the study must incorporate those resources most likely to be employed at the time of the formation of the state. A simple econometric model is used to examine the effect of non-fuel minerals (including gold, silver, and iron) and coal on the date of statehood when controlling for when the land was originally purchased and whether or not the territory that would eventually become a state that bordered an ocean. The results of the study were consistent with the hypothesis that states formed more quickly in areas that contained a greater measure of non-fuel minerals and coal.

After having found evidence to support that more expropriative governments form and that governments form more quickly in areas with more natural resources, the next chapter of my dissertation looks at the effect of resource abundance on the size of government. 


\subsection{The Impact of Resource Abundance on the Size of Government}

This chapter focuses on how resource intensity affects the size of government and the governments' policies with regards to takings and transfers. Natural resources are likely

to lead to a larger government because there is an excess of wealth for the government to expropriate. A large government (as measured by government spending and transfers and subsidies as a share of Gross State Product) is problematic because it fosters an environment conducive to rent-seeking where people will try to use the prevailing institutions to take the wealth of others. This type of activity, named unproductive entrepreneurship by Baumol (1990), crowds out productive entrepreneurship, which consists of those innovative activities that create wealth and further enhance the development of an economy. It is through this channel that an abundance of natural resources can hurt economic growth.

In order to analyze the effect of natural resource abundance on the size of government, this study looks at the effect of resource intensity, as measured by the share of the primary sector (agriculture, forestry, fishing, and mining) in Gross State Product (GSP), on the size of government as measured by the Economic Freedom of North America (EFNA) area 1 score. This study is unique in that it is one of the first to examine a determinant of economic freedom in an attempt to see why some states are more free than others. The study includes controls that could also account for the size of government. This includes constitutional variables as constitutions were designed to constrain the government so that it continued to serve its citizens rather than overpower them. The model also controls for the length of time in which the government has been 
in existence, as governments tend to grow over time and various political variables are also included in this analysis.

Prior research has concluded that natural resource abundance leads to institutions of lower quality and increased rent seeking. This study confirms those results as resource intensity is negatively related to the EFNA area 1 score, indicating that more resource abundant states have larger governments. This is particularly true for point resources which must be mined out of the ground and are, therefore, immobile, as compare to diffuse resources which can more easily move in classical Tiebout fashion (Tiebout, 1956) when confronted with an overly-intrusive government. Those states with an economy more centered around mining point resources are more likely to suffer from larger governments.

While chapters two and three have focused on the connection between resource abundance and the formation and size of governments, the next chapter looks at how the interaction between resource intensity and institutional quality affects development across U.S. states.

\subsection{The Resource Curse: Institutions, Economic Freedom, and Growth Across U.S. States}

The focus of this chapter is the answer to the question concerning whether or not natural resource abundance is only negatively related to growth in states with poor institutions. In their international study, Mehlum, Moene, and Torvik (2006) found that some areas with an abundance of natural resources were able to excel economically while others exhibited the low or negative growth consistent with the resource curse literature. They used an interaction term that combines various measures of intuitional quality and 
resource intensity to find that the resource curse only exists in those countries with poor grabber-friendly institutions, while those countries with what they determined to be high quality producer-friendly institutions exhibited higher growth in the presence of natural resources.

The study in this chapter takes a similar approach by incorporating an interaction term that combines resource intensity and institutional quality (as measured by the Economic Freedom of North America composite score) into a growth model similar to the one used by Papyrakis and Gerlaugh in the only other study of the effect of resource intensity on growth across the United States. This model examines the effect of this interaction term on economic growth (measured as the average growth in GSP per capita from 1986-2005) across all 50 U.S. states using the same education, investment, research and development, and openness variables that Papyrakis and Gerlaugh (2006) used in their study. This model also includes initial GSP per capita to control for convergence and variables to measure population density, the climate, and whether or not the state has any coastline as these have been concluded to be important variables in determining the growth of an economy (Gallup, Mellinger, and Sachs, 1998).

The study finds that the interaction term is positively related to development, which supports the international result that only economies with poor institutions suffer from the resource curse. Those states with better institutional quality will actually grow faster in the presence of natural resources. The study goes further in finding that an economic freedom score greater than 6.22 on a 10 point scale is necessary for the effect of natural resources on growth to turn positive. This provides evidence for the finding 
that good institutions consistent with low taxation, a free labor market, and less government involvement within the economy are necessary to lift the resource curse. 


\section{Chapter 2}

\section{The Resource Curse: Evidence from U.S. State Constitutional Structures}

\subsection{Introduction}

The term 'resource curse' refers to the seemingly paradoxical, inverse relationship between abundant natural resources and economic growth. This mysterious correlation has garnered a great deal of attention from economists who have set out to uncover the reason for this negative linkage. Sachs and Warner $(1995 ; 2001)$ were the first to establish that the countries with a higher endowment of natural resources suffer from slower economic growth. Their research was followed by many others who likewise explored the resource curse and its potential causes on a global scale. ${ }^{1}$

Only recently has the examination of the resource curse focused on the subnational level, where resources were measured as the share of the primary sector (forestry, fishing, agriculture, and mining) in Gross State Product (GSP). The first to do so was Papyrakis and Gerlaugh (2006) who confirmed its existence across U.S. states. This strikingly clear relationship, virtually identical to what is found in international cross-country data, is shown in Figure 1.1.

\footnotetext{
${ }^{1}$ See, for example, Leite and Weidmann (1999), Gylfason (2001), Bulte, Damania, and Deacon (2005), Isham, Woolcock, Pritchett, and Busby (2005), and Stevens (2005).
} 
Figure 1.1: Resource Abundance and Growth Across U.S. States ${ }^{2}$

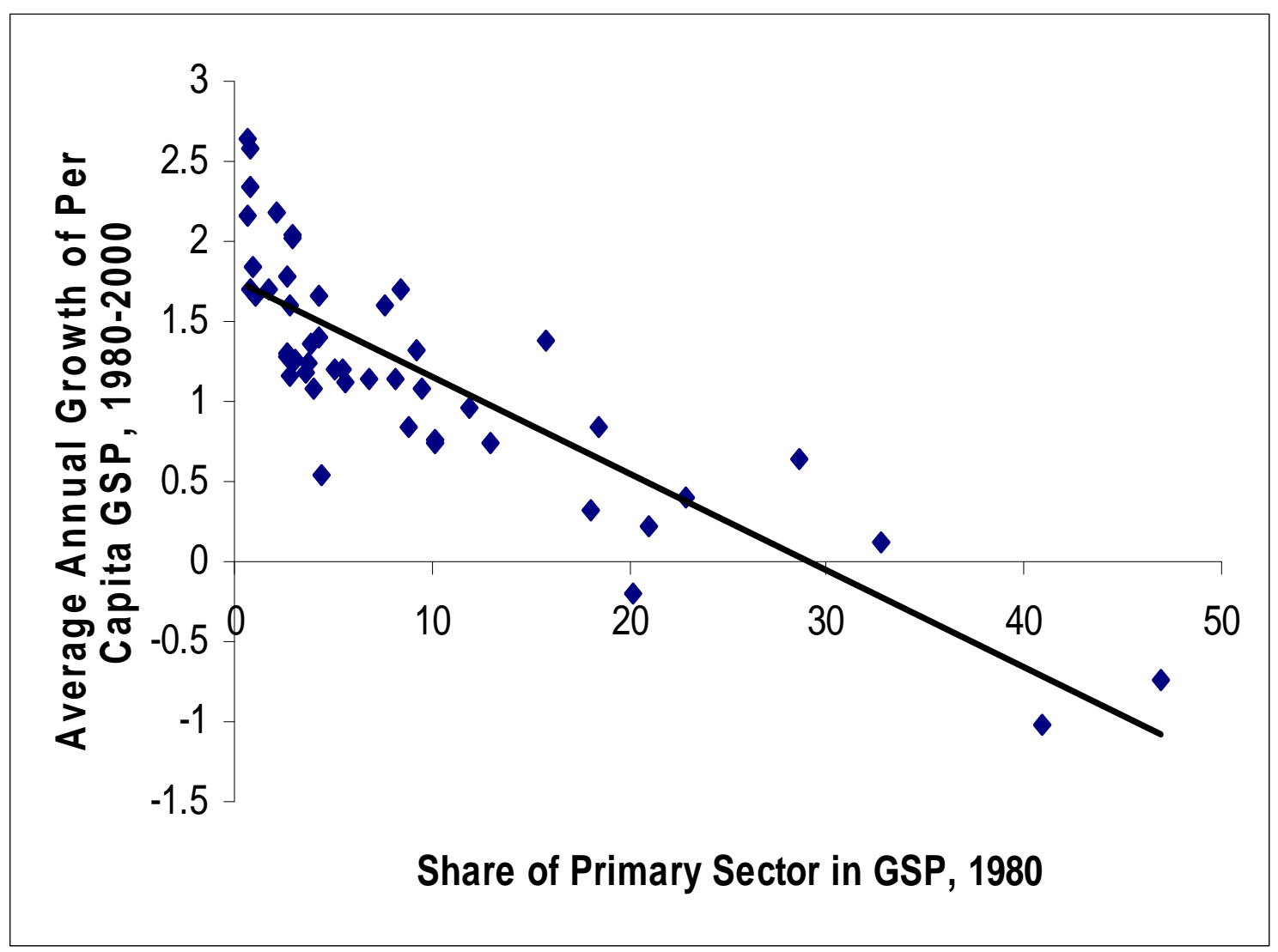

While this inverse relationship is extremely robust, the cause behind it remains elusive. Sachs and Warner argue that resources will crowd out other important factors that are conducive to economic growth. One such explanation is that the resource intensive industry will utilize most or all of an economy's scarce resources, which will negatively impact other sectors of the economy by increasing the opportunity cost of production. However, there is little empirical evidence to support this explanation (Stevens, 2005).

Another possible explanation is "Dutch Disease", which is a term coined after the Netherlands discovered natural gas fields and, consequently, experienced a decline in

\footnotetext{
${ }^{2}$ Figure is from Dunn (2008)
} 
their manufacturing sector. Dutch Disease occurs when a nation experiences a sudden and extreme increase in wealth (in this case, caused by the discovery of natural resources) which leads to an appreciation of the country's real exchange rate, making its manufactured products less competitive in world markets, further crowding out the manufacturing sector. Some other authors, such as Gylfason (2001), partially attribute the resource curse to the impact of resource industries on education levels and human capital accumulation. Resource industries tend to be manual-labor intensive and, thus, increase the (relative) opportunity cost of higher education and the development of human capital.

More recently, authors have begun to explore 'institutional' connections to the resource curse. A country's formal institutions are those codified through law and written documents such as a constitution, and 'good institutions' refer to those that are conducive to wealth creation; such as an impartial administration of justice through the legal system, secure property rights, and constitutionally constrained and limited government. 'Bad institutions' refer to those that reward attempts to expropriate and redistribute wealth, and infringe on the rights of citizens.

The 'institutional' explanation of the resource curse is that poor quality institutions tend to evolve in resource abundant areas because they can focus on wealth extraction from these immobile resources, and that these weak institutions are what is then responsible for weaker economic performance.

Underground mineral resources are both fixed in location and highly valuable, which make them prime targets for expropriation through taxation and regulation. Other industries such as manufacturing can more easily escape bad governments by relocating 
to other jurisdictions in classic Tiebout (1956) fashion, and the intergovernmental competition for their location (and subsequent tax revenues) leads to better institutions. The inability of resources to escape expropriative governments leads to a less competitive government policy structure and a set of institutions that are focused on rent extraction. Poor institutions, coupled with powerful special-interest groups focused on expropriating the value of the resources, draws entrepreneurial talent away from productive activities and drives this talent toward plunder and other forms of unproductive entrepreneurship, following the terminology of Baumol (1990).

According, then, to this line of logic, 'bad' institutions tend to evolve in resource abundant areas, and these weak institutions are then what is responsible for worse economic performance. The evidence of an institutional connection to the resource curse is strong and growing. Leite and Weidmann (1999) provide evidence that natural resources leads to increased corruption and rent-seeking. Isham, Woolcock, Pritchett, and Busby (2005) find this to be especially true for point resources, which are those resources that are tied to a narrow geographic area (such as gold, coal, and other minerals) as opposed to diffuse resources which are more mobile (such as food and agricultural products). Dunn (2008) finds that this result holds at the sub-national level as she concludes that point resource abundance is positively correlated with measures of rent-seeking across the U.S. states. Anecdotally, West Virginia's heavy resource dominated economy seems to be in line with this argument given its horrible economic record and $50^{\text {th }}$ place ranking in the Economic Freedom of North America institutional quality ranking. 
In this paper, we provide the first direct evidence that those institutions which are more expropriative, or of a lower quality, are indeed more likely to evolve in resource abundant areas. We do so by examining both how rapidly state governments evolved within newly acquired territories of the early United States, and by direct examination of the constitutional structures of states. We focus our constitutional analysis on the most likely state where this type of expropriative structure would evolve: Wyoming. While many of the valuable natural resources currently produced in the states were discovered after these areas were already states, Wyoming is the clearest case of a state evolving in an area with known, valuable, resource production. Wyoming became a state in 1890 , more than 40 years after major deposits of coal and other mineral resources were discovered. There was already a robust mining industry in the Wyoming Territory at the time of the writing of Wyoming's state constitution.

Today, Wyoming is by far the nation's leading producer of coal with over 450 million short tons (or 40 percent of the U.S. total) produced there annually. The second ranking state in coal production, West Virginia, produces only about one third as much coal. Wyoming's annual coal production is larger than the total amount mined in the next five largest coal producing states combined. The taxation of these resources accounts for over one-third of Wyoming's total tax revenue, ranking second only to state sales tax revenue.

Far from the Rawlsian ideal notion of a "veil of ignorance" in constitutional formation (Rawls, 1971), Wyoming is unique in that it had significant known stocks and production levels of valuable natural resources before the constitution was written. That is the state constitution (and the entire state governmental structure itself) was formed 
and adopted in the presence of resources to expropriate. Section 2.2 of this chapter develops a simple model to show the implications of resource abundance on the expropriative nature of government. Section 2.3 looks at the state constitution of Wyoming in more detail. Section 2.4 examines our hypothesis that state governments are likely to form more rapidly in those territories which were rich in known natural resource wealth to expropriate. Section 2.5 concludes.

\subsection{A Model of Expropriation}

The fact that point resources lead to tax bases with a lower elasticity with respect to the tax rate imposed on them implies that leviathan governments will both levy higher tax rates and expropriate more revenue. This can be demonstrated mathematically.

Let $B_{i}$ be a state $i$ 's tax base, which is a negative function of the tax rate, $t_{i}$, imposed per Equation 1:

$$
\mathrm{B}_{\mathrm{i}}=\alpha-\beta * \mathrm{t}_{\mathrm{i}}
$$

The state's revenue, $\mathrm{R}_{\mathrm{i}}$, is the tax base times the tax rate, following Equation 2:

$$
\mathrm{R}_{\mathrm{i}}=\mathrm{B}_{\mathrm{i}} * \mathrm{t}_{\mathrm{i}}
$$

Combining yields:

$$
\mathrm{R}_{\mathrm{i}}=\left(\alpha-\beta * \mathrm{t}_{\mathrm{i}}\right) * \mathrm{t}_{\mathrm{i}}=\alpha^{*} \mathrm{t}_{\mathrm{i}}-\beta * \mathrm{t}_{\mathrm{i}}^{2}
$$

A leviathan, revenue-maximizing, government will set the tax rate that maximizes revenue which can be found through differentiation:

$$
\partial \mathrm{R}_{\mathrm{i}} / \partial \mathrm{t}_{\mathrm{i}}=\alpha-2 * \beta * \mathrm{t}_{\mathrm{i}}=0
$$

Which implies a revenue-maximizing tax rate of:

$$
\mathrm{t}_{\mathrm{i}}=\alpha / 2 * \beta
$$


and filling back into the revenue equation (Equation 3) produces a corresponding (maximized) level of revenue of:

$$
\mathrm{R}_{\mathrm{i}}=\alpha^{*}\left(\alpha / 2^{*} \beta\right)-\beta *\left(\alpha / 2^{*} \beta\right)^{2}=\alpha^{2} / 4^{*} \beta
$$

Within the scope of the resource curse argument, the difference between resource abundant states and non-resource abundant states is in the responsiveness of the tax base to the tax rate, or the parameter $\beta$. This parameter will be smaller to indicate the less responsive tax base in resource abundant areas. Letting $\beta_{\mathrm{R}}$ represent its value in resource abundant states, $\beta_{\mathrm{NR}}$ represent its value in non-resource abundant states, and imposing the logic that $\beta_{\mathrm{R}}<\beta_{\mathrm{NR}}$ makes it possible to conclude that leviathan governments in areas with resources will impose higher tax rates, and expropriate more revenue. This is clear in Equations 5 and 6 , as with $\beta$ in the denominator of both, lower values of $\beta$ lead to higher values for the tax rate and tax revenue, that is $t_{R}>t_{N R}$ and $R_{R}>R_{N R}$. The next section will provide a constitutional analysis of the formation of expropriative governments around an abundance of natural resources.

\subsection{State Constitutional Analysis: The Case of Wyoming}

If indeed it is the 'evolution of poor institutions' explanation that is responsible for the resource curse, rather than other competing hypothesis, we should be able to see evidence in the constitutional structures of such areas. Here we use Wyoming as a case study ${ }^{3}$. As mentioned earlier, Wyoming is unique in that known and valuable resources were clearly present at the time this state government evolved. Coal was first discovered in Wyoming

\footnotetext{
${ }^{3}$ For more information about the formation of Wyoming as a state please see Shearer (2004) and Larson 1999.
} 
in 1843, some forty years prior to statehood. The constitution of the State of Wyoming was adopted on September 30, 1889 and ratified by the voters of Wyoming 6,272 (in favor) to 1,903 (opposed) on November 5, 1889.

While Wyoming's constitution has been amended many times since adoption, unlike in most other states Wyoming's original constitution remains in force and has not been replaced by another constitution. In terms of length, Wyoming has the eleventh longest state constitution. When looking through the state constitution of Wyoming one can easily find words and phrases that look to be the seeds from which an expropriative Leviathan government will grow.

Wyoming's constitution includes significant language aimed at controlling and regulating the activities of corporations. For example, section 97-10-002 of the Wyoming constitution appropriately labeled "Control by State" reads as follows:

All powers and franchises of corporations are derived from the people and are granted by their agent, the government, for the public good and general welfare, and the right and duty of the state to control and regulate them for these purposes is hereby declared. The power, rights and privileges of any and all corporations may be forfeited by willful neglect or abuse thereof. The police power of the state is supreme over all corporations as well as individuals.

Another section, 97-10-006, even restricts corporations to one line of business:

No Corporation shall have the power to engage in more than one general line or department of business, which line of business shall be distinctly specified in its charter of incorporation.

This was amended in 1960 to loosen this requirement. Language such as this indicates a government bent on excessive control over an economy and its resources. 


\subsection{1: Taxation}

While all state constitutions address the power of taxation, the vast majority mention it only in a general context, and do not single out specific industries or products for special taxation. Consistent with the hypothesis at hand, however, in addition to the general statements normally found, Wyoming's constitution also devotes substantial space specifically to the taxation of natural resources. For example, section 97-15-003 reads:

All mines and mining claims from which gold, silver and other precious metals, soda, saline, coal, mineral oil or other valuable deposit, is or may be produced shall be taxed in addition to the surface improvements, and in lieu of taxes on the lands, on the gross product thereof, as may be prescribed by law; provided, that the product of all mines shall be taxed in proportion to the value thereof.

In addition to specifically mentioning the taxation of coal being produced, Wyoming also constitutionally specifies that the state will tax coal deposits that aren't even in production yet in section 97-15-002:

All coal lands in the state from which coal is not being mined shall be listed for assessment, valued for taxation and assessed according to value.

The constitution does mention potentially limiting the tax on land, but this limit does not apply if the revenue goes to support the states educational or charitable institutions, alleviate the state debt, or payoff the interest on the state debt, providing an escape clause from any binding limits on the property taxation of resources.

While the two passages above seem to give the state almost unlimited power to tax coal and other resources, in addition to property taxes the state constitution also outlines an additional severance tax on coal and the other fixed natural resources to be mined in section 97-15-019:

The Legislature shall provide by law for an excise tax on the privilege of severing or extracting minerals, of one and one-half percent $(11 / 2 \%)$ on 
the value of the gross product extracted. The minerals subject to such excise tax shall be coal, petroleum, natural gas, oil shale, and such other minerals as may be designated by the Legislature. Such tax shall be in addition to any other excise, severance or ad valorem tax.

Wyoming's constitution also prescribes what the state will do with natural

resource properties that come into possession of the state through forfeiture and inheritance taxes and acquisitions in section 97-7-002:

...the net proceeds of lands and other property and effects that may come to the state by escheat or forfeiture, or from unclaimed dividends or distributive shares of the estates of deceased persons; all moneys, stocks, bonds, lands and other property now belonging to the common school funds. Provided, that the rents for the ordinary use of said lands shall be applied to the support of public schools and, when authorized by general law, not to exceed thirty-three and one-third $(33$ 1/3) per centum of oil, gas, coal, or other mineral royalties arising from the lease of any said school lands may be so applied.

From the above passages, we believe it is clear that the Wyoming state government designed its constitutional structure around the intent to extract revenue from the abundance of natural resources found within the territory's borders. These provisions are entirely absent from most other state constitutions, even in other coal-producing states (neither West Virginia's first or second constitution, for example, specifically mentions the word "coal" nor outlines a specific tax on mineral resources). We believe this is significant evidence in favor of the 'bad institutions evolve in resource abundant areas' hypothesis about the origins of the natural resource curse.

\subsection{2: Regulation}

In addition to taxation, a state government can also expropriate through regulation.

Those areas with a large amount of natural resources are likely to have governments which will excessively regulate these resources, with an intent to transfer wealth to other 
organized interest groups. At the time of Wyoming's constitution, perhaps the most powerful interest group in the state was organized labor. Clause after clause of the Wyoming constitution regulates and micromanages business contracts in the natural resource industry with a clear intent to transfer wealth to the organized labor unions. Section 97-01-022 refers to labor compensation more generally:

The rights of labor shall have just protection through laws calculated to secure to the laborer proper rewards for his service and to promote the industrial welfare of the state.

Perhaps most strikingly are the state constitutional provisions that mandate employment contracts both in terms of hours worked and the content of the employment contracts. For example, Wyoming's state constitution regulates what determines a full day's work within the mines in section 97-19-002:

Eight (8) hours actual work shall constitute a lawful day's work in all mines, and on all state and municipal works.

Interestingly, mines are treated in language similar to state and municipal employees, as if mining was government employment. Also, interestingly, all other types of private businesses (other than mines) are excluded from this constitutional provision.

Wyoming's original constitution regulated who was allowed to work in the mining industry. Specifically, women of any age were not allowed to be employed in the mine. This is mentioned in section 97-9-003:

... no woman or girl of any age shall be employed or permitted to be in or about any coal, iron, or other dangerous mines for the purpose of employment therein... 
This regulation initially limited the mining companies hiring choices and reduced the productive capacity of the mines. It was eventually repealed from the Wyoming constitution, but not until November 7, $1978^{4}$

The nature of the mining employment contract is also specifically regulated in Wyoming's constitution. Section 97-19-007 prohibits employment contracts from containing provisions that exempt the employer from liability for workers' personal injuries.

It shall be unlawful for any person, company or corporation, to require of its servants or employees as a condition of their employment, or otherwise, any contract or agreement whereby such person, company or corporation shall be released or discharged from liability or responsibility, on account of personal injuries received by such servants or employees, while in the service of such person, company or corporation, by reason of the negligence of such person, company or corporation, or the agents or employees thereof, and such contracts shall be absolutely null and void.

The above two provisions, normally found in statutory laws passed to appease labor union interest groups in other states, are uniquely integrated into Wyoming's actual constitution, unlike in any other state.

Wyoming's constitution also specifies provisions related to workplace injuries and the compensation due employees in Section 97-9-004:

For any injury to person or property caused by willful failure to comply with the provisions of this article, or laws passed in pursuance hereof, a right of action shall accrue to the party injured, for the damage sustained thereby, and in all cases in this state, whenever the death of a person shall be caused by wrongful act, neglect or default, such as would, if death had not ensued, have entitled the party injured to maintain an action to recover damages in respect thereof, the person who, or the corporation which would have been liable, if death had not ensued, shall be liable to an action

\footnotetext{
${ }^{4}$ It is interesting to notes that Wyoming has often been referred to as the equality state because it was the first state to grant women the right to vote. However, in their initial constitution, they enacted regulation specifically designed to keep women out of working in the mines, and this regulation persisted until the late 1970's.
} 
for damages notwithstanding the death of the person injured, and the legislature shall provide by law at its first session for the manner in which the right of action in respect thereto shall be enforced.

Mostly unlike in modern times, labor union strikes in the mining industry in the late 1800 s and early 1900s were fraught with violence. Striking workers often resorted to violence against potential replacements, company managers, and company property. With local law enforcement unions aligned strongly with the labor unions in most states, these activities were often backed, rather than prosecuted, by law enforcement units. Because of this, companies generally hired private security to help them during times of labor union strikes, and these units moved from one state to another depending on where they were most needed within the company. In a one-of-a-kind constitutional provision, Wyoming actually prevents companies from hiring this type of private protection to enforce their own rights to life and property. This is contained in Section 97-19-006:

No armed police force, or detective agency, or armed body, or unarmed body of men, shall ever be brought into this state, for the suppression of domestic violence, except upon the application of the legislature, or executive, when the legislature cannot be convened.

The net effect of this prohibition is to greatly enhance the ability of the labor unions to use violence to expropriate wealth from mining companies through labor contracts.

Wyoming's state constitution also calls for the regulation of mining operations as to be controlled and assessed by a mining inspector in section 97-9-001:

There shall be established and maintained the office of inspector of mines, the duties of which shall be prescribed by law.

The constitution also calls for very specific regulation of the nature of mining operations in section 97-9-002:

The legislature shall provide by law for the proper development, ventilation, drainage and operation of all mines in this state. 
Finally, making sure not to overlook other areas of expropriation, the state constitution goes on to explicitly mention that eminent domain shall never be interpreted so as to prevent the taking of property of companies for public use in section 97-10-014:

Exercise of the power and right of eminent domain shall never be so construed or abridged as to prevent the taking by the legislature of property and franchises of incorporated companies and subjecting them to public use the same as property of individuals.

\subsection{3: Other Areas of Rent Extraction: Railroads and Water}

In those states with an extensive abundance of natural resources, particularly in those areas concerned with mining, the railroad industry flourished as a vital component in transporting this valuable resource to market. These railroad lines, like natural resources, can be the objects of rent extraction by the state government. True to form, the Wyoming state government imposes a significant amount of regulation on the railroad industry aimed at transferring wealth.

In the Wyoming constitution, railroads are required to build and operate a station at any town within 4 miles of a railroad line. In fear that the railroad companies (in this case Union Pacific) would find ways to escape this provision through altering where they placed the lines, the constitution explicitly forbids railroads from locating lines away from towns in an effort to avoid having to comply with this law in section 97-10-019:

No railroad company shall construct or operate a railroad within four (4) miles of any existing town or city without providing a suitable depot or stopping place at the nearest practicable point for the convenience of said town or city, and stopping all trains doing local business at said stopping place. No railroad company shall deviate from the most direct practicable line in constructing a railroad for the purpose of avoiding the provisions of this section. 
The constitution clearly forces rail and other service providers, who were generally only serving the mines, to also provide these services to local townships, even if unprofitable.

Section 97-10-012 states:

Railroad and telegraph lines heretofore constructed or that may hereafter be constructed in this state are hereby declared public highways and common carriers, and as such must be made by law to extend the same equality and impartiality to all who use them, excepting employees and their families and ministers of the gospel, whether individuals or corporations.

To ensure railroads are profitable enough to cross-subsidize the legally required passenger services for small towns, the state government also created barriers to entry that reduced competition in section 97-10-018:

No foreign railroad or telegraph line shall do any business within this state without having an agent or agents within each county through which such railroad or telegraph line shall be constructed upon whom process may be served.

Railroads were also subject to specific reporting requirements to the state in section 9710-013:

Every railroad corporation or association operating a line of railroad within this state shall annually make a report to the auditor of state of its business within this state, in such form as the legislature may prescribe.

Complying with these regulations increases the cost of doing business and makes it more difficult for businesses to thrive in such states. However, since the railroads have to transport the resources, the railroad industry is as immobile as the resources and are, therefore, as subject to the whims of an evolving intrusive and extractive state government in Wyoming.

In addition to the railroad industry; the extraction, socialization, and control over the valuable water supply is also a target in Wyoming's state constitution. The 
constitution set up a complete system of water allocation, unique among states to that time, and it established the principle of state ownership of the resource in section 97-1031:

Water being essential to industrial prosperity, of limited amount, and easy of diversion from its natural channels, its control must be in the state, which, in providing for its use, shall equally guard all the various interests involved.

The state then sets up a board of control as well as a state engineer with which to control the use of all water in the state.

\subsection{4: Summarizing the Evidence from Wyoming's Constitution}

While the evidence is clear that a resource curse exists, that is, that areas with abundant natural resources tend to have worse economic performance, the avenue through which this occurs is hotly debated in the literature. Recently, arguments have been made that the explanation is institutional. That is, because fixed natural resources are easy targets for expropriation, the types of governments that evolve in areas with abundant resources tend to be 'worse' governments in terms of being focused on wealth extraction and transfer, rather than being properly constrained in a manner that promotes individual liberty, freedom, and wealth creation. If this institutional hypothesis is true, the prediction is clear: we should see evidence of this in the documents that created governments in areas with known valuable resources. Wyoming is a unique case study as the state was formed well after known coal and other mineral deposits were already discovered and being mined. Our examination of the provisions of Wyoming's original state constitution clearly illustrates this exact scenario. Unlike other states in which resources were discovered after statehood, Wyoming's rather long constitution devotes 
substantial space and language to the taxation and regulation of natural resources. The fact that other state constitutions do not contain this language is striking. We believe this is strong evidence in favor of the institutional explanation for the existence of the resource curse.

\subsection{The Rise of Governments}

As a final piece of evidence as to the validity of the institutional explanation of the resource curse, we test a novel prediction we believe will hold if this explanation is accurate. The institutional explanation, as normally stated, postulates only that bad government institutions will evolve, however, we believe a natural extension would be the idea that governments should be likely to form more rapidly in areas with these resources to expropriate. That is, in a given geographic area, the areas likely to have governments evolve first will be those areas with known fixed resources to expropriate.

Continuing with our use of evidence from the U.S. states, we now examine how rapidly state governments were to evolve within territorial acquisitions of the early United States. The land area of the United States was expanded through several major territorial acquisitions. Each of these territories then, though time, was divided up into many states that were controlled by different state governments. The question we ask is, holding constant the date the land area became a U.S. territory, is it true that the first areas carved out into states, with official state governments, were those with more abundant resources to expropriate. We explore this using regression methodology by estimating the following equation: 
Date of Statehood $=\alpha_{0}+\beta_{1} *$ Date of Territorial Acquisition or Purchase $+\beta_{2} *$ Resource

$$
\text { Abundance }+\varepsilon
$$

We also include a control variable reflecting whether the land bordered an ocean (and thus had potential for a seaport). After dropping Alaska, Hawaii, and West Virginia, we are left with 47 states in our sample. ${ }^{5}$

Ideally we would like to include a variable that measured the value of the known resources at the time when each state was still a territory. Unfortunately, the data on mining and resources by state does not exist that far back. As a proxy, which is clearly less than ideal, we use a recent measure of resources, but attempt to make it more reflective of only those resources likely to be known at the time of statehood. For example, oil and natural gas were mostly discovered in the United States after these areas became states and the importance of these resources had not yet been fully realized, and therefore, the value of these should not be included. The resources at play in the early days of settlement were mostly the non-fuel minerals such as gold, silver, and iron. So our measure of resources consists of the value (in millions of dollars) of non-fuel minerals for the year 2000. A list of all of the variables used in our empirical analysis along with a description and source can be found in Appendix 2A. Appendix 2B contains a complete list of all resources included in the non-fuel minerals variable.

In terms of the predicted signs on the coefficients, we would expect the coefficient on territorial acquisition to be positive, showing that a later date of land acquisition results in a later date of statehood, while, consistent with the institutional

\footnotetext{
${ }^{5}$ We focus our analysis on the continental U.S. and exclude Alaska and Hawaii (the last two U.S. states, who were long time territories). Also, West Virginia warranted special treatment. It was originally part of Virginia until 1863. To be consistent we treat Virginia as it would have been at the time of statehood by including the value of any resources from West Virginia in the data for Virginia, and dropping West Virginia from the analysis.
} 
explanation for the resource curse, we would expect the coefficient on resource abundance to be negative and significant, indicating that governments evolved sooner in these areas.

Table 2.1: Formation of Governments and Resource Abundance

\begin{tabular}{|c|c|c|c|}
\hline \multirow[t]{2}{*}{ Dependent Variable: } & \multicolumn{3}{|c|}{ Date of Statehood } \\
\hline & (1) & (2) & (3) \\
\hline Constant & $\begin{array}{c}-796.1447^{\star \star} \\
(2.21)\end{array}$ & $\begin{array}{l}-592.3624^{\star \star} \\
(2.08)\end{array}$ & $\begin{array}{c}-417.2117 \\
(1.41)\end{array}$ \\
\hline $\begin{array}{l}\text { Date of Territorial } \\
\text { Acquisition or Purchase }\end{array}$ & $\begin{array}{l}1.4653^{\star \star \star} \\
(7.26)\end{array}$ & $\begin{array}{l}1.3609^{\star * \star} \\
(8.57)\end{array}$ & $\begin{array}{l}1.2644^{\star \star \star} \\
(7.67)\end{array}$ \\
\hline $\begin{array}{l}\text { Abundance of Nonfuel } \\
\text { Minerals }\end{array}$ & $\begin{array}{c}-0.0114^{*} \\
(1.77)\end{array}$ & $\begin{array}{c}-0.0113^{\star \star} \\
(2.26)\end{array}$ & $\begin{array}{c}-0.0091^{*} \\
(1.81)\end{array}$ \\
\hline Coastal Border & & $\begin{array}{c}-35.3260^{\star \star \star} \\
(5.40)\end{array}$ & $\begin{array}{c}-37.8178^{\star \star \star} \\
(5.77)\end{array}$ \\
\hline Abundance of Coal & & & $\begin{array}{l}-5.31^{*} \\
(1.75)\end{array}$ \\
\hline Observations & 47 & 47 & 47 \\
\hline $\mathrm{R}^{2}$ & 0.5696 & 0.7435 & 0.7608 \\
\hline F-statistic & $29.12^{\star \star \star}$ & $41.54^{\star \star \star}$ & $33.40^{\star \star \star}$ \\
\hline Prob > F & 0.0000 & 0.0000 & 0.0000 \\
\hline
\end{tabular}

Absolute t-ratios for the independent variables are shown in parenthesis.

The symbols $* * *, * * *$ denote a $10 \%, 5 \%$, and $1 \%$ level of significance, respectively.

Table 2.1 shows the results of our regressions. The results are consistent with our hypothesis. Controlling for the date of territorial acquisition, our measure of resource abundance in the state's subsequent territory (non-fuel minerals) is negative and significant. In our second specification we also include a dummy variable for whether the state's eventual area bordered an ocean. As mentioned earlier, the potential for ports and easier transportation generally led to more rapid settlement so it might be important to include this as a control variable. Interestingly, it is possible to argue that these seaport 
areas are similar fixed resources that might lead to faster government formation to expropriate this value. However, we simply include it as a control as our focus is on traditional natural (mineral) resources mentioned in the previous resource curse literature.

The inclusion of the coastal border variable strengthens our results and improves our model. The dummy variable for coastal border is positive and significant as expected, while the coefficient on our variable of interest remains relatively unchanged in magnitude, although it increases in significance due to the reduced unexplained error resulting from including the coastal border variable.

Our non-fuel measure of resources potentially excludes one resource that would have been known in some states at the time of statehood-the value of coal. The inclusion of current coal reserves or production is more problematic than the other minerals as current coal reserves were only partially discovered that far back. Luckily, coal production data goes back much further than the similar data for other natural resources, so we can use a measure farther back in time to limit the problems with undiscovered coal being included in the variable. Our third regression shown in Table 1 includes the number of long tons of coal produced by state in the year 1900 .

The results show that both measures of resource abundance are negative and significant. This again confirms our hypothesis that governments evolved more quickly in states with a larger amount of wealth in the form of natural resources to expropriate.

\subsection{Conclusion}

While the existence of a resource curse is unquestioned, the path through which it happens is hotly debated. Recently institutional explanations have begun to show promise at the international level. This line of reasoning suggests that resource abundant 
areas have poor economic performance because they suffer from the presence of bad political and legal institutions aimed at expropriating wealth from resource industries which are fixed in location. We add to this literature by examining the evidence on state government formation in the United States.

We hypothesize that state constitutional structures should reflect this expropriative bent if this logic is true. By examining the unique case of Wyoming, a state that was formed clearly after the presence of valuable resources were known, we find clear evidence in favor of the institutional explanation for the resource curse. Wyoming's lengthy constitution contains pages of material explicitly aimed at taxing and regulating natural resource industries.

We also examine an interesting hypothesis we propose, which is that if this institutional explanation is true we would expect land areas with resources to witness the formation of governments more rapidly. Using evidence from U.S. territorial acquisitions, we indeed find that those areas likely to become states first within each territory were precisely those with known fixed resources to expropriate.

Based on our analysis, we conclude that the 'curse' that exists with having abundant natural resources is, indeed, a result of the expropriative institutions that develop in resource abundant areas. After having established the connection between resource intensity and the formation of expropriative governments, the next chapter examines the connection between resource intensity and the growth of governments beyond their productive capacity. 


\section{Chapter 3}

\section{The Impact of Resource Abundance on the Size of Government}

\subsection{Introduction}

The idea that an abundance of natural resources is negatively correlated with economic growth is now commonly known as the resource curse. There has been a great deal of research conducted on this seemingly paradoxical economic phenomenon since the seminal work of Sachs and Warner $(1995 ; 2001)$ first explained this link. There exists a large number of theories of how natural resources can negatively impact growth. Sachs and Warner (2001) summarized most of these explanations as the idea that an abundance of natural resources crowds out certain activities and these activities are what drives growth. However, because there is debate over what drives growth, there is debate about how resources adversely affect various economies.

The United States provides a fertile ground for the examination of the resource curse because there are similarities across states which eliminate differences that may be problematic when trying to analyze this concept at the international level, but there are also enough differences in resource endowments and other growth-related factors across states to allow for such research. However, only recently have scholars attempted to study this link at the state level (Papyrakis and Gerlagh, 2006; Dunn, 2008). This paper continues this regional analysis on the resource curse by providing the link between natural resource abundance and government size, transfers, and subsidies, as measured by the area 1 score of the Economic Freedom of North America Index.

The link between economic freedom and growth has been widely examined at both the international and regional level and is well established in previous literature 
(Gwartney, Lawson, and Block, 1996; Gwartney and Lawson, 2002; Easton and Walker, 1997; Karabegovic et. all, 2008; Karabegovich et all, 2008; Dawson, 2003; Cole, 2003; 2005). So it is natural to study economic freedom as one of the growth causing variables to be crowded out by natural resources. The next section of this chapter will explore the idea of the resource curse and its potential causes. Section 3.3 examines the research on economic freedom and growth to establish the link of economic freedom as a transmission channel through which the resource curse operates. Section 3.4 provides a discussion of the data including the advantages to studying the resource curse at the state level across U.S. States, an explanation of the measure for resource abundance, and theories behind the use of all control variables. Section 3.5 presents the empirical model and its results. Section 3.6 offers robustness checks and the final section concludes.

\subsection{Economic Freedom Leads to Higher Growth}

The relationship between economic freedom and growth has been well established in the previous literature at both the international and regional level. The Economic Freedom of the World Index measures the degree of economic freedom across five major areas. These areas are government size, legal structure and security of property rights, access to sound money, freedom to exchange with foreigners, and regulation of credit, labor, and business (Gwartney and Lawson, 2003). Easton and Walker (1997) used this measure to show that economic freedom is an important component of growth when examining the market socialist state of China and other communist-era countries. The authors concluded that an increased reliance on economic freedom would lead to greater prosperity for China, while continued emphasis on market socialism would result in less 
growth. The authors compared Hong Kong (the country with the highest level of economic freedom) in 1985 with other communist-era countries in which similar 1985 data was available. This includes the countries of Czechoslovakia, Hungary, Poland, and Romania. They concluded that "were those countries to have had Hong Kong's level of economic freedom, per capita steady-state income would have been $\$ 6,350$ higher on average" (Easton and Walker, pg. 332).

The research by Cole $(2003 ; 2005)$ shows the EFW index to be a large contributor to growth across alternative empirical frameworks. Economic freedom was significantly positively related to real GDP per capita in both a neoclassical growth model and in a model including geographical variables (Cole 2003; 2005). This research established a correlation between economic freedom and growth, but it did not establish causality. Dawson (2002) provided evidence that the overall level of economic freedom granger causes differences in economic growth at the international level.

The relationship between economic freedom and growth has also been established at the regional level. The Economic Freedom of North America index establishes the economic freedom levels of all 50 U.S. states as well as some Canadian Provinces by examining government size, taxation, and labor market freedom across these areas. The calculation of economic freedom across states is slightly different than at the national level. Many of the categories that are used in the world index have too little variance to be effectively used when calculating economic freedom across states. Factors such as private ownership of banks, monetary policy, freedom to own foreign currency, and the right to international exchange are fairly identical across states. Using the Economic Freedom of North America Index, Karabegovic et. all (2003) conclude that economic 
freedom is a significant contributor to economic growth. Both the level and growth of economic freedom have a significant impact on growth in per capita GDP.

The reason behind this consistent positive relationship between economic freedom and growth can be explained with Baumol's work on entrepreneurship (Baumol, 1990). Baumol used evidence from cross-cultural historical examples to show that there are two types of entrepreneurship, productive and unproductive, and that productive entrepreneurship fuels growth. Productive entrepreneurship consists of innovations that enhance the quality of goods and services so as to make people better off. When a new good or service is invented or an old good or service is improved upon, then people have access to something that makes their life better, whether that be a new drug that cures disease and improves health or a new technology that reduces cost and saves time. When these improved goods and service are bought and sold then both the buyer and seller are made better off and wealth is created. Indeed, the economic pie is being expanded. Policies consistent with economic freedom provides fewer barriers to entry in the development of these goods and services and fosters an environment that allows entrepreneurs to profit from their discoveries which increases the incentive for further development (Baumol, 1990).

Conversely, unproductive entrepreneurship involves developing new and innovative techniques for taking the wealth of others through some coercive act or manipulation of the legal system. The discovery of a new method of using the law or prevailing institutions to redistribute wealth from one person to another does not increase the size of the economic pie, but rather transfers the pieces from one person to another. Policies that are inconsistent with economic freedom impose more barriers to innovation, 
discourages ingenuity, and encourages behavior consistent with rent-seeking, or the transfer of wealth from others. An institution that encourages unproductive entrepreneurship will crowd out the research and discovery that is necessary for the growth and development of an economy. For this reason, economic freedom is a vital component for growth. In the next section, this chapter discusses the various possible explanations of how resource abundance influences growth and provides a connection between resource endowment and unproductive entrepreneurship.

\subsection{The Resource Curse}

The idea that an abundance of natural resources would have a negative effect on economic growth seems counterintuitive. However, this inverse relationship has been demonstrated within an extensive number of studies. This link was first formally identified in the seminal works of Sachs and Warner (1995; 2001). Their first study (Sachs and Warner, 1995) found evidence for a basic negative relationship between a high value of resource-based exports and economic growth, even after controlling for initial income levels, international trade policies, bureaucracy, inequality, investment, and terms of trade volatility. In a future study, Sachs and Warner (2001) found evidence to further strengthen the idea of the resource curse. They concluded that the inverse relationship between resource abundance and growth also holds when controlling for previous growth rates, geography, and climate. Several recent studies have even classified natural resource abundance as one of the ten most robust variables when empirically studying international economic growth (Sachs and Warner, 2001). Establishing the existence of the resource curse is only part of the analysis of this 
economic occurrence. There has also been an extensive amount of research done to determine the cause of this relationship and the various channels through which the resource curse operates.

A possible explanation for the resource curse is a concept known as Dutch disease, which was named after the experience of the Netherlands in 1970 when the discovery of natural gas fields significantly hurt the nation's manufacturing sector (Stevens, 2005). Dutch disease occurs when any factor (in this case resource abundance) causes a sudden and extreme increase in a country's wealth that leads to an appreciation of the real exchange rate. This will cause the country to import more as foreign goods are now cheaper in the face of the new exchange rate and export less as its goods are now relatively more expensive to the rest of the world. This reduction in the exporting sector will hurt the country's efforts at industrialization, and thus, retard the county's level of long-run growth. There have been multiple studies that have investigated Dutch disease as a possible cause of the resource curse. The results are conflicting, with only some in favor of it as a possible explanation.

An argument has also been made for the idea that resource investment projects, which are prevalent in resource abundant nations, will claim the use of the country's other scarce resources and, thus, prevent the economy from further development. However, this explanation for the resource curse is only relevant in small countries with large investment projects and most of the work on this explanation tends to be theoretical in nature, as opposed to empirical (Stevens, 2005).

A great deal of research has evolved around the institutional explanation of the resource curse on which this paper is focused. The main idea that persists throughout this 
literature is that resource abundance may lead the government to make policies that hurt economic growth. It has been suggested that the development of natural resources will increase the expectations of the general population who will, in turn, pressure the government to quick and ill-advised decisions which increases government growth and control (Stevens, 2005). The operation of the resource curse through the institutional channel may also be the result of increased corruption, rent-seeking, and government transfers that are spawned from resource abundance. This is especially true with point resources, which are minerals that must be mined out of the ground and are, therefore, relatively immobile, as institutions that develop around this type of resource can be more extractive and controlling without fear of the resource moving away. Point resources are, thus, a more likely channel to bad institutions than diffuse resources, which are more mobile factors such as agriculture, forestry, and fishing that are more likely to leave when confronted with an undesirable level of government. An abundance of natural resources may also lead a nation's government to make bad industrial policy, poor investment decisions, and polices on subsidies and trade openness that could adversely affect growth (Stevens, 2005).

Most of the research on the resource curse has been done at the international level using cross-country data. So far, very little research has been done at the state level. This is surprising given that the United States would seem to provide a fertile research ground for looking at the relationship between institutions and the resource curse. Papyrakis and Gerlaugh (2006) provide the first regional study of the resource curse by extending their international work on the indirect transmission channels of resource abundance to the United States. The authors find that natural resource abundance is 
negatively correlated with growth across states because resource abundance decreases investment, schooling, openness, and expenditure on research and development, while increasing corruption.

The relationship between natural resource abundance and rent-seeking was also analyzed at the regional level. Recent research provides both theoretical and empirical support for the idea that resource abundance will lead to a higher level of rent seeking through the use of the severance tax across the United States (Dunn, 2008). The author finds that this holds for both point and diffuse resources. The idea that resource abundance can hurt growth through an increase in rent-seeking is consistent with Baumol's theory of entrepreneurship (Baumol, 1990). It is likely that natural resource abundance can negatively affect growth through increased rent-seeking, which would replace productive entrepreneurship. The relationship between natural resources and poor institutions that foster unproductive entrepreneurship has been studied at the international level (Isham, Woolcock, Pritchett, and Busby, 2005) but not yet at the regional level. There are several connections between an abundance of particular types of resources and institutional quality across countries.

One connection is contained within what the researchers call "rentier effects". This occurs when revenues can be extracted from a few easily controlled resources, such as the owners of point resources who, due to the nature of their assets, are unable to leave the jurisdiction of the state government. Access to these revenues gives the government the ability to repress dissent from the population either directly through force or indirectly through the provision of benefits, infrastructure projects, or transfers, all of which can crowd out productive entrepreneurship (Isham, Woolcock, Pritchett, and 
Busby, 2005). Another connection between point resources and the institutional impact on development is delayed modernization. Institutions that cater to the maintenance of their point resource-owning revenue sources will resist industrialization because it will spawn competitors who will threaten the power of the status quo. This attempt to squash industrialization will likely reduce efforts at productive entrepreneurial activities, leaving people to become less concerned with innovation and more likely to explore the acquisition of wealth through rent-seeking. Combining these two connections, one can see that resource abundance extinguishes the flames of productive ambition, while strengthening the hold of government (Isham, Woolcock, Pritchett, and Busby, 2005).

While this connection between resource abundance and institutional quality has been examined internationally, it has yet to be looked at on a regional level making the research on the indirect channels through which the resource curse operates in the United States very informative, but not exhaustive. Papyrakis and Gerlagh (2006) are able to demonstrate resource abundance's affect on investment, schooling, openness, research and development, and corruption, while Dunn (2008) concludes that resource abundance will increase rent-seeking. This paper expands upon this previous research by analyzing the effect of resource abundance on economic freedom, particularly with regard to government size, transfers, and subsidies at the state level. This has important implications as economic freedom has been repeatedly shown to be an important factor in growth. The next section discusses the data used to examine this relationship. 


\subsection{Data}

This chapter adds to the relatively small amount of research of the resource curse at the regional level. The use of state level data may be a more effective way to study the idea of the resource curse as U.S. data have several advantages over international data. First, U.S. data are more structured in that the same type of data that measures the same things over the same period tends to be available for all states. International data is often subject to measurement problems, inaccurate records, and missing observations. Indeed, Sachs and Warner (1995) had to drop a number of countries from their study because of measurement problems. ${ }^{6}$ Using U.S. data will eliminate some of the unobservable variability in the data set. Second, the use of U.S. data will eliminate the possibility that it is the volatility of the exchange rate and terms of trade that lead to the resource curse. This common explanation for the resource curse will not apply in this case as all states are subject to the same currency. Finally, states in the U.S. tend to have the same military history which is not true across countries. This eliminates the possibility that growth is really being determined by some aspect of military history that is hard to measure and incorporate into a model.

A similar argument can be made about the difference in culture between states as compared to between countries (Papyrakis and Gerlaugh, 2006). While it could be argued that different states have very different cultures, this cultural variance is not likely to be as high as it is at the global level, so using U.S. data will reduce the chance of a cultural variable, which is also difficult to measure, biasing the results. The elimination of these confounding factors along with different state governments that have varying

\footnotetext{
${ }^{6}$ Although, in this case the authors maintain that if they included those countries then it would have only made their results stronger.
} 
levels of economic freedom make the United States a fertile ground for studying the relationship between resource abundance and the government size, transfers, and subsidies that foster unproductive entrepreneurship. Another important contribution of this study is that it is the first to attempt to analyze the determinants of an area of economic freedom at the state level. In other words, it is the first to try to answer the important question of why some states are more economically free than others.

A measure of institutional quality that is frequently used in dealing with U.S. state governments is the North American Economic Freedom Index which consists of three important categories that are all calculated at the state or province level (Karabegovic et al., 2003; Karabegovic et al., 2008). Area 1 consists of measures for the size of the government in the economy. This includes the general consumption expenditures by government as a percentage of GDP as well as transfers and subsidies as a percentage of GDP. This represents how much the government has moved beyond the minimal productive and protective functions necessary for efficiency. Subsidies and transfers represent the removal of property without compensation which impedes on economic freedom and provides a fertile environment for the growth and development of rentseeking behavior. For these reasons, area 1 is the focus of this paper.

The Economic Freedom of North America Index is calculated both with and without the inclusion of federal government spending for U.S. states. Since this paper is primarily concerned with the effect of resource abundance on the state government, the study will employ the score that consists only of state government spending. This total score is measured on a scale from 1-10 with 10 being the most free and 1 being the least free. The independent variable of interest in this study is resource intensity which is 
measured as the total share of agriculture, forestry, fishing, and mining as a percentage of Gross State Product (GSP). This is, admittedly, not a perfect measure of resource intensity as it involves the reliance on resources rather than the amount of resources within the state. Also, over the time period being studied, all states have experienced a general decrease in resource intensity. However, share of the primary sector in GDP (or GSP for states) is the most common measure for resource intensity in the literature concerning the resource curse and it is the measure used by both Papyrakis and Gerlagh (2006) and Dunn (2008) in the only other papers that examine the resource curse across U.S. states. To analyze the effect of resource abundance on institutional size and transfers that are consistent with unproductive entrepreneurship, this paper will focus on the area 1 score of economic freedom. To be consistent with the literature on resource intensity's effect on institutional quality, resources should be negatively correlated with this area 1 score of government size.

It is not expected that resource intensity for the year $t$ will have a large effect on the development of the institutional quality of the state government in year $t$. Rather it is more expected that resource intensity at some time $t$ will have an effect on the institutions that develop over time as a result of this initial endowment and, indeed, this is how the resource curse is typically studied. Papyrakis and Gerlagh (2006) use share of the primary sector (agriculture, forestry, fishing, and mining) in GSP for 1986 to study growth over the whole period from 1986-2000. This paper will also use a similar lagged approach to the resource variable by using the five year average of the share of the primary sector in GSP from 1986-1990 as the independent variable and economic freedom for 2005 as the dependant variable. The five year average for the measure of 
resources reduces the potential for any effect to be influenced by an atypical amount of resource intensity that could accompany any single year while still allowing for a time period great enough for institutions to adapt policies to their initial level of resources. ${ }^{7}$

Since this is the first attempt to examine the determinants of an area of economic freedom at the state level, a discussion of the control variables and the theory behind their use is necessary. A complete description of every variable used and its source is located in Appendix 3A. Historical, political, and constitutional variables are considered to explain the differences in institutions across states connected by one overarching federal government. These variables provide key institutional differences across states that are otherwise very similar. The first control variable is the number of constitutions that the state has adopted. Buchanan (1990) highlights constitutions as a mutually agreed upon constraint on individuals behavior. An individual agrees to limit his or her behavior in response to others limiting their own behavior and this is how government is originally formed. These constitutions are designed to not only constrain individuals' behavior, but to constrain the government's behavior as well. Thus, constitutions are paradoxical in nature as they grant the government the right to exclusive use of coercive power, but also try to limit that power. Public choice economists have recently studied constitutional reform as a way of restraining the government (Cullis and Jones, 1998). In this way, constitutions serve as a cage designed to keep the government from growing. Therefore, the number of constitutions could serve as an attempt to measure the state's efforts at restraining the growth of government and have a positive effect on economic freedom. However, constitutional reform could also result in political instability or be caused by

\footnotetext{
${ }^{7}$ For robustness, I ran the regressions again using only the 1986 measure for resource intensity and it did not significantly change the results. These results are presented later in this chapter.
} 
excessive institutional turmoil, which would result in a negative relationship between constitutions and economic freedom. It is initially unclear which effect is stronger and so the direction of the effect of this variable is initially unknown.

However, there has also been a great deal of study concerning constitutional decline. This theory says that over the years constitutions have become weaker constraints on government due to the rise in special interest groups and better political tactics. Also, an increased preference for more government may lead to the adoption of weaker constitutions in recent times (Cullis and Jones, 1998). The effective date of the present constitution is, therefore, included to measure the effect of constitutional decline on economic freedom. Measured as the year that the present constitution was adopted, it should be negatively correlated with economic freedom as the leviathan-constraining chains of newly adopted constitutions are likely to be weaker than that of older ones.

The average of the number of amendments that were adopted to the present constitution over the time period being studied is also included in the analysis. Given the rise of special interest groups, political tactics such as logrolling, and previously mentioned constitutional decay, it seems reasonable to expect that newly adopted constitutional amendments will likely weaken the constitutions constraints on government size and economic interference. Therefore, it is likely that the average number of adopted amendments will have a negative effect on economic freedom.

The natural tendency for the government to grow over time, a concept that has come to be known as Wagner's Law, cannot be ignored when trying to analyze the determinants of government size (Cullis and Jones, 1998). There are numerous theories concerning the reasons behind government's growth, ranging from bureaucratic 
monopolies (Niskanen, 1968) to displacement effects (Peacock and Wiseman, 1961), but it does appear that governments are greater in size and economic contamination the longer that they are in existence. The date of statehood is then included into this study to capture this effect. This is measured by the year in which the state and its government were admitted into the union. To be consistent with the theories of government growth, this variable would be positively correlated with economic freedom indicating that newer state governments are not as intrusive as older ones. However, it is also likely that older governments formed more quickly in areas with greater natural resources in an effort to expropriate the wealth consistent with these areas. It is unclear which effect would be stronger, and so the effect of this variable is unclear.

The final control variable included in this study is the average share of republicans in the state house of representatives (calculated by dividing the number of republicans in the house by the total number of members of the state house of representatives and multiplied by 100 to formulate a percent using the data available from various editions of the Book of the States) for the period 1986-2005. A discussion of the senate and the governor as alternative political variables will be provided in section 6 . It is unclear how this variable would be related to this measure of government size, subsidies and transfers, but it is necessary to include a political variable when analyzing why state governments may be different. Equipped with an explanation behind the theories and uses of these variables, the next section of this chapter will explain the empirical model as well as the results. 


\subsection{Empirical Model and Results}

Past literature has shown resource abundance to be negatively correlated with quality of institutions, therefore, it is expected that resource abundance would negatively impact economic freedom. Table 3.1 below looks at the two states with the highest and lowest scores in area 1 of the Economic Freedom of North America Index (Delaware and Alaska, respectively) as measured in 2005 , their level of resource intensity measured as the share of the primary sector in GSP, and growth in GSP per capita from 1986-2005. One can easily see that Delaware relies much less on natural resources than Alaska and has a much higher level of economic freedom and growth in GSP per capita:

Table 3.1: Delaware vs. Alaska

\begin{tabular}{|c|c|c|}
\hline State & Delaware & Alaska \\
\hline Economic Freedom (area 1) & 8.7 & 3.8 \\
\hline Resource Intensity & 0.814 & 30.349 \\
\hline Growth in GSP per Capita & 5.74 & 3.08 \\
\hline
\end{tabular}

Much of the literature focuses on the idea that resource abundance will pressure the government to get involved in the control and use of these resources (frequently doing so by making quick and ill-advised decisions). The international literature focuses on resource intensity's tendency to cause the government to make growth retarding decisions concerning industrial policies, investment, and subsidies. Thus, this literature points to the use of the area 1 score of the Economic Freedom Index of North America concerning government size and transfers and subsidies as the most likely to be affected by differences in resource endowment ${ }^{8}$. Therefore, the first regression uses a cross section of 49 states to examine the following model'

\footnotetext{
${ }^{8}$ The composite economic freedom score was used as the dependent variable and the effect of resource intensity on the composite score is also negative, but insignificant. Resources most negatively affect economic freedom through area 1 which includes government size and transfers.

${ }^{9}$ Nebraska was dropped form the analysis due to the fact they have a bicameral legislation and, therefore, no data available for the average share of Republicans in the state house of representatives
} 
EFNA Area $1_{2005}=a_{0}+b_{1}$ Resource Intensity ${ }_{1986-1990}+b_{2} Z+\epsilon$

Where $\mathrm{Z}$ is the list of control variables mentioned in the previous section. Table 3.2 provides the results. As predicted, resource intensity is negatively correlated with the area 1 score for economic freedom and the result is significant at the 5\% level. The results indicate that a $17.4 \%$ increase in the reliance on natural resources will lower this component of economic freedom by 1 full point on the 10 point scale. This is considerable since the most economically free state, Delaware, and the least economically free state with regard to area 1 , Alaska, are separated by less than 5 points.

The control variables have the predicted sign with the number of constitutions, the number of adopted amendments, and share of republicans in the house of representatives all significant at the 5\%,10\%, and $1 \%$ levels, respectively. Each constitution a state has increases area 1 freedom by 0.22 points, indicating that constitutions do serve as a way to constrain government growth and intervention. Each amendment that gets adopted to the present constitution has a smaller negative effect of reducing economic freedom by 0.002 points. The share of the republicans in the house of representatives is the most statistically significant control variable, with a $1 \%$ increase leading to a 0.026 increase in the area 1 score of economic freedom. The variables effective date of the present constitution and the date of statehood are not significant, but the effective date of the present constitution appears to be approaching significance at the $10 \%$ level. The model itself is significant at the $5 \%$ level.

It is also noteworthy to examine the effects that different kinds of resources have on government size. The literature on the relationship between institutions and resource intensity states that the type of resource makes a significant difference in how institutions 
react and evolve to this resource wealth. Point resources, which consist of those that must be mined from their current location, are relatively immobile and, therefore, more likely to lead to extractive and controlling governments then diffuse resources which are more mobile and can leave when institutional factors become too burdensome. Therefore, it would be expected that point resources are a much more significant contributor to government size and reduced economic freedom than diffuse resources. This finding would be consistent with that of Bulte, Damania, and Deacon (2005) who find that point resources are more associated with bad institutions than diffuse resources. In order to analyze this hypothesis, model 1 is adjusted to examine point and diffuse resources separately, giving us models 2 and 3 .

EFNA Area $1_{2005}=\mathrm{a}_{0}+\mathrm{b}_{1}$ Point Resources ${ }_{1986-1990}+\mathrm{b}_{2} \mathrm{Z}+\epsilon$

EFNA Area $1_{2005}=\mathrm{a}_{0}+\mathrm{b}_{1}$ Diffuse Resources ${ }_{1986-1990}+\mathrm{b}_{2} \mathrm{Z}+\epsilon$ 
Table 3.2: Resource Intensity Average from 1986-1990

\begin{tabular}{|c|c|c|c|}
\hline Dependant Variable: & $\begin{array}{c}\text { EFNA Area } 1 \text { score } \\
\text { (1) }\end{array}$ & (2) & (3) \\
\hline Constant & $\begin{array}{l}6.2848 \\
(0.69)\end{array}$ & $\begin{array}{l}6.7515 \\
(0.90)\end{array}$ & $\begin{array}{l}16.2705^{\star \star} \\
(2.22)\end{array}$ \\
\hline Resource Intensity & $\begin{array}{c}-0.0575^{\star *} \\
(2.63)\end{array}$ & & \\
\hline Point Resources & & $\begin{array}{c}-0.0556^{\star *} \\
(2.66)\end{array}$ & \\
\hline Diffuse Resources & & & $\begin{array}{l}.0293 \\
(0.40)\end{array}$ \\
\hline \# Constitutions & $\begin{array}{l}0.2195^{\star \star} \\
(2.27)\end{array}$ & $\begin{array}{l}0.2087^{\star \star} \\
(2.20)\end{array}$ & $\begin{array}{l}0.1251 \\
(1.28)\end{array}$ \\
\hline $\begin{array}{l}\text { Date of Present } \\
\text { Constitution }\end{array}$ & $\begin{array}{c}-0.0055 \\
(1.65)\end{array}$ & $\begin{array}{c}-0.005 \\
(1.51)\end{array}$ & $\begin{array}{c}-0.0037 \\
(1.03)\end{array}$ \\
\hline $\begin{array}{l}\text { \# of adopted } \\
\text { amendments }\end{array}$ & $\begin{array}{l}-0.0023^{\star} \\
(1.93)\end{array}$ & $\begin{array}{c}-0.0022^{\star} \\
(-1.86)\end{array}$ & $\begin{array}{c}-0.0016 \\
(1.26)\end{array}$ \\
\hline Statehood & $\begin{array}{c}0.0059 \\
(1.28)\end{array}$ & $\begin{array}{c}0.0046 \\
(1.07)\end{array}$ & $\begin{array}{c}-0.0019 \\
(0.46)\end{array}$ \\
\hline $\begin{array}{l}\text { Share of Republicans } \\
\text { in House }\end{array}$ & $\begin{array}{c}0.0265^{\star * *} \\
(2.85)\end{array}$ & $\begin{array}{c}0.0237^{\star \star} \\
(2.59)\end{array}$ & $\begin{array}{c}0.0207^{\star *} \\
(1.98)\end{array}$ \\
\hline observations & 49 & 49 & 49 \\
\hline $\mathrm{R}^{2}$ & 0.2848 & .0 .2871 & 0.1706 \\
\hline F-statistic & $2.79 * \star$ & $2.82^{\star \star}$ & 1.44 \\
\hline Prob > F & 0.0226 & 0.0214 & 0.2225 \\
\hline
\end{tabular}

Note: Absolute t-ratios for the independent variables are shown in parenthesis. The symbols $*, *, * * *$ denote a $10 \%, 5 \%$, and $1 \%$ level of significance, respectively.

The results confirm the expectations that point resources are more significantly related to a lower level of this component of economic freedom then diffuse resources. The results in regression 2 are nearly identical to those in regression 1 indicating that much of the effect of resource intensity on economic freedom comes through point resources. The 
variable point resources is still negative and significant at the $5 \%$ level and the expected signs of the control variables are still present and unchanged from the first model with the number of constitutions and the share of republicans in the state house of representatives significant at the $5 \%$ level and number of amendments adopted significant at the $10 \%$ level. The model also remains significant at the $5 \%$ level.

The results for regression 3 are drastically different from that of regression 1 and 2. When analyzing the effect of diffuse resources on government size, the coefficient of the resource variable changes and it is no longer significant. Also, all of the control variables except for share of republicans in the house are insignificant and the model itself loses its significance. The study then concludes that point resources are a more powerful explanatory variable of changes in government size than diffuse resources, a result at the regional level that is consistent with the findings of Bulte, Damania, and Deacon (2005) at the international level. Indeed, the effect of total resources on freedom comes almost entirely through point resources. This indicates that poor institutions are more likely to evolve around immobile resources that are unable to move when they are faced with an overly-intrusive government.

\subsection{Robustness}

For robustness, this study measures the effect of resource intensity in the year 1986 on government size. This measure for resources is more consistent with that used in the Papyrakis and Gerlagh paper (2006) than the five year average. In this new model, whose results are illustrated in Table 3.3, the share of republicans in the house variable drops in significance from the $1 \%$ level to the $5 \%$ level, but otherwise, the results, are 
little changed from that of the original model indicating that both measures for resource intensity are valid for this study.

Table 3.3: Resource Intensity in 1986

\begin{tabular}{|c|c|c|c|}
\hline Dependant Variable: & EFNA Area 1 score & & \\
\hline & (1) & (2) & (3) \\
\hline Constant & $\begin{array}{l}7.4662 \\
(0.96)\end{array}$ & $\begin{array}{c}8.397794 \\
(1.12)\end{array}$ & $\begin{array}{c}16.0009^{* *} \\
(2.19)\end{array}$ \\
\hline $\begin{array}{l}\text { Resource Intensity } \\
\text { (1986) }\end{array}$ & $\begin{array}{l}-0.0531^{* *} \\
(2.21)\end{array}$ & & \\
\hline Point Resources (1986) & & $\begin{array}{c}-0.0535^{\star \star} \\
(2.27)\end{array}$ & \\
\hline $\begin{array}{l}\text { Diffuse Resources } \\
\text { (1986) }\end{array}$ & & & $\begin{array}{l}0.0165 \\
(0.24)\end{array}$ \\
\hline \# Constitutions & $\begin{array}{c}0.2130 * * \\
(2.14)\end{array}$ & $\begin{array}{c}0.2080^{\star \star} \\
(2.12)\end{array}$ & $\begin{array}{c}0.1275 \\
(1.31)\end{array}$ \\
\hline $\begin{array}{l}\text { Date of Present } \\
\text { Constitution }\end{array}$ & $\begin{array}{l}-0.0055 \\
(1.62)\end{array}$ & $\begin{array}{c}-0.0051 \\
(1.51)\end{array}$ & $\begin{array}{c}-0.0038 \\
(1.06)\end{array}$ \\
\hline $\begin{array}{l}\text { \# of adopted } \\
\text { admendments }\end{array}$ & $\begin{aligned}- & 0.0022^{*} \\
& (1.84)\end{aligned}$ & $\begin{array}{c}-0.0021^{*} \\
(1.78)\end{array}$ & $\begin{array}{c}-0.0016 \\
(1.27)\end{array}$ \\
\hline Statehood & $\begin{array}{l}0.0048 \\
(1.03)\end{array}$ & $\begin{array}{l}0.0038 \\
(0.87)\end{array}$ & $\begin{array}{c}-0.0017 \\
(0.40)\end{array}$ \\
\hline $\begin{array}{l}\text { Share of Republicans } \\
\text { in House }\end{array}$ & $\begin{array}{c}0.0259 * * \\
(2.69)\end{array}$ & $\begin{array}{c}0.0230^{\star *} \\
(2.47)\end{array}$ & $\begin{array}{c}0.0213^{\star \star} \\
(2.06)\end{array}$ \\
\hline $\begin{array}{l}\text { observations } \\
\mathrm{R}^{2}\end{array}$ & $\begin{array}{c}49 \\
0.2543\end{array}$ & $\begin{array}{c}49 \\
0.2587\end{array}$ & $\begin{array}{c}49 \\
0.1686\end{array}$ \\
\hline
\end{tabular}

Note: Absolute t-ratios for the independent variables are shown in parenthesis. The symbols $*, * *, * * *$ denote a $10 \%, 5 \%$, and $1 \%$ level of significance, respectively.

Table 3.4 includes the results when the share of republicans in the state senate as opposed to the share of republicans in the state house of representatives is used in a 
model that is otherwise unchanged from the original. The two variables cannot be used together in the same model due to the fact that they are highly correlated. The results are largely unchanged, but curiously the share of republicans in the state senate is not significant, while the share of republicans in the state house of representatives was significant at the $1 \%$ level. The model also loses some of its explanatory power.

Table 3.4: Share of Republicans in Senate as Political Variable

\begin{tabular}{|c|c|c|c|}
\hline Dependant Variable: & EFNA Area 1 score & & \\
\hline & (1) & (2) & (3) \\
\hline Constant & $\begin{array}{l}5.6152 \\
(0.68)\end{array}$ & $\begin{array}{l}6.1903 \\
(0.78)\end{array}$ & $\begin{array}{c}16.5339^{* *} \\
(2.17)\end{array}$ \\
\hline Resource Intensity & $\begin{array}{c}-0.0519 \text { ** } \\
(2.23)\end{array}$ & & \\
\hline Point Resources & & $\begin{array}{c}-0.0552^{\star \star} \\
(2.49)\end{array}$ & \\
\hline Diffuse Resources & & & $\begin{array}{l}.0660 \\
(0.91)\end{array}$ \\
\hline \# Constitutions & $\begin{array}{c}0.1823^{*} \\
(1.78)\end{array}$ & $\begin{array}{c}0.1821^{*} \\
(1.82)\end{array}$ & $\begin{array}{c}0.0957 \\
(0.95)\end{array}$ \\
\hline $\begin{array}{l}\text { Date of Present } \\
\text { Constitution }\end{array}$ & $\begin{array}{c}-0.0052 \\
(1.47)\end{array}$ & $\begin{array}{c}-0.0049 \\
(1.40)\end{array}$ & $\begin{array}{c}-0.0033 \\
(-0.89)\end{array}$ \\
\hline $\begin{array}{l}\text { \# of adopted } \\
\text { amendments }\end{array}$ & $\begin{aligned}- & 0.0022^{*} \\
& (1.72)\end{aligned}$ & $\begin{array}{c}-0.0021^{*} \\
(1.71)\end{array}$ & $\begin{array}{c}-0.0015 \\
(1.16)\end{array}$ \\
\hline Statehood & $\begin{array}{c}0.0058 \\
(1.18)\end{array}$ & $\begin{array}{l}0.0051 \\
(1.12)\end{array}$ & $\begin{array}{c}-0.0022 \\
(0.50)\end{array}$ \\
\hline $\begin{array}{l}\text { Share of Republicans } \\
\text { in Senate }\end{array}$ & $\begin{array}{c}0.0142 \\
(1.43)\end{array}$ & $\begin{array}{l}0.013 \\
(1.34)\end{array}$ & $\begin{array}{c}0.0104 \\
(0.83)\end{array}$ \\
\hline $\begin{array}{l}\text { observations } \\
\mathrm{R}^{2}\end{array}$ & $\begin{array}{c}49 \\
0.1863\end{array}$ & $\begin{array}{c}49 \\
0.2067\end{array}$ & $\begin{array}{c}49 \\
0.1074\end{array}$ \\
\hline
\end{tabular}

Note: Absolute t-ratios for the independent variables are shown in parenthesis. The symbols $* * *, * * *$ denote a $10 \%, 5 \%$, and $1 \%$ level of significance, respectively. 
Due to the unicameral state legislation employed by Nebraska, it was eliminated in all of the previous regressions. In an effort to include Nebraska in the study, the political variable was changed to the average with which the governor belongs to the republican political party over the years 1986-2005. This variable is given the value of 1 for each year the governor is republican and 0 otherwise. The average is then taken over the years 1986-2005. This also does little to change the results, which are presented in Table 3.5, except that again the new political variable is insignificant. Evidently, when one wants to achieve a smaller government and a lower level of transfers and subsidies it is better to bet on the house. The explanation for this interesting result is left for future research. 
Table 3.5: Republican Governor as Political Variable

\begin{tabular}{|c|c|c|c|}
\hline Dependant Variable: & EFNA Area 1 score & & \\
\hline & (1) & (2) & (3) \\
\hline Constant & $\begin{array}{l}6.4829 \\
(0.77)\end{array}$ & $\begin{array}{c}6.2503 \\
(0.78)\end{array}$ & $\begin{array}{c}16.8983^{* *} \\
(2.22)\end{array}$ \\
\hline Resource Intensity & $\begin{aligned}- & 0.0457^{*} \\
& (1.94)\end{aligned}$ & & \\
\hline Point Resources & & $\begin{array}{c}-0.0537^{\star *} \\
(2.40)\end{array}$ & \\
\hline Diffuse Resources & & & $\begin{array}{l}0.0917 \\
(1.35)\end{array}$ \\
\hline \# Constitutions & $\begin{array}{l}0.1716 \\
(1.63)\end{array}$ & $\begin{array}{c}0.1757^{\star} \\
(1.72)\end{array}$ & $\begin{array}{l}0.0934 \\
(0.91)\end{array}$ \\
\hline $\begin{array}{l}\text { Date of Present } \\
\text { Constitution }\end{array}$ & $\begin{array}{c}-0.006 \\
(1.60)\end{array}$ & $\begin{array}{c}-0.0055 \\
(1.54)\end{array}$ & $\begin{array}{c}-0.0036 \\
(0.95)\end{array}$ \\
\hline $\begin{array}{l}\text { \# of adopted } \\
\text { amendments }\end{array}$ & $\begin{array}{c}-0.0026^{*} \\
(1.90)\end{array}$ & $\begin{array}{l}-0.0025^{*} \\
(1.93)\end{array}$ & $\begin{array}{c}-0.0018 \\
(1.29)\end{array}$ \\
\hline Statehood & $\begin{array}{c}0.0063 \\
(1.24)\end{array}$ & $\begin{array}{l}0.006 \\
(1.30)\end{array}$ & $\begin{array}{c}-0.002 \\
(0.44)\end{array}$ \\
\hline Republican Governor & $\begin{array}{l}0.5675 \\
(0.95)\end{array}$ & $\begin{array}{l}0.4545 \\
(0.77)\end{array}$ & $\begin{array}{c}0.3382 \\
(0.54)\end{array}$ \\
\hline observations & 50 & 50 & 50 \\
\hline $\mathrm{R}^{2}$ & 0.1493 & 0.1846 & 0.1129 \\
\hline
\end{tabular}

Note: Absolute t-ratios for the independent variables are shown in parenthesis. The symbols $* * *, * * *$ denote a $10 \%, 5 \%$, and $1 \%$ level of significance, respectively.

It is also appropriate to check the effect of natural resources on various measures of government size in order to verify the robustness of the result. The area 1 score that has been the focus of this analysis is broken into three sub-areas. Area 1a is the general consumption expenditures by the government as a percentage of Gross State Product. This is also calculated on a 1-10 scale with a higher score indicating more freedom 
through a lower level of consumption expenditures. Some may believe that this may be a more accurate measure of government size than the entire Area 1 score. Therefore, this variable is used as the dependent variable to study the effects of resources on government size in a model otherwise identical to that given by equation 1 . To be consistent with the hypothesis, resource intensity should be negatively and significantly correlated with the Area 1a score. This was also tested across both point and diffuse resources, and the results are consistent with those of the original model. That is, the higher the level of the state's resource intensity, particularly with regard to point resources, the lower the level of the Area 1a score indicating a larger and more intrusive government. Table 3.6 presents these results: 
Table 3.6: Area 1A - Government General Consumption Expenditures as a Percentage of GDP

\begin{tabular}{|c|c|c|c|}
\hline Dependant Variable: & \multicolumn{3}{|c|}{$\begin{array}{l}\text { Area } 1 \mathrm{~A} \text { Score: Government General Consumption } \\
\text { Expenditures as a Percentage of GDP }\end{array}$} \\
\hline Constant & $\begin{array}{l}9.3033 \\
(0.91)\end{array}$ & $\begin{array}{c}13.7107 \\
(1.34)\end{array}$ & $\begin{array}{l}24.8070^{* \star} \\
(2.48)\end{array}$ \\
\hline Resource Intensity & $\begin{array}{c}-0.0952^{* * *} \\
(-3.28)\end{array}$ & & \\
\hline Point Resources & & $\begin{array}{c}-0.0794^{\star \star \star} \\
(2.77)\end{array}$ & \\
\hline Diffuse Resources & & & $\begin{array}{c}-0.0847 \\
(0.85)\end{array}$ \\
\hline \# Constitutions & $\begin{array}{l}0.1514 \\
(1.18)\end{array}$ & $\begin{array}{l}0.1154 \\
(0.89)\end{array}$ & $\begin{array}{l}0.0139 \\
(0.10)\end{array}$ \\
\hline $\begin{array}{l}\text { Date of Present } \\
\text { Constitution }\end{array}$ & $\begin{array}{c}-0.0015 \\
(0.33)\end{array}$ & $\begin{array}{c}-0.0004 \\
(0.08)\end{array}$ & $\begin{array}{c}0.0004 \\
(0.08)\end{array}$ \\
\hline $\begin{array}{l}\text { adopted } \\
\text { admendments }\end{array}$ & $\begin{array}{l}-0.0016 \\
(1.03)\end{array}$ & $\begin{array}{c}-0.0013 \\
(0.81)\end{array}$ & $\begin{array}{l}-0.0006 \\
(0.38)\end{array}$ \\
\hline Statehood & $\begin{array}{l}-0.0012 \\
(-0.19)\end{array}$ & $\begin{array}{c}-0.0047 \\
(0.81)\end{array}$ & $\begin{array}{c}-0.0115^{\star *} \\
(2.01)\end{array}$ \\
\hline $\begin{array}{l}\text { Share of } \\
\text { Republicans } \\
\text { in House }\end{array}$ & $\begin{array}{c}0.0367^{\star * *} \\
(2.98)\end{array}$ & $\begin{array}{c}0.0318^{\star *} \\
(2.54)\end{array}$ & $\begin{array}{c}0.0334^{* *} \\
(2.34)\end{array}$ \\
\hline observations & 49 & 49 & 49 \\
\hline $\mathrm{R}^{2}$ & 0.3848 & 0.3465 & 0.2401 \\
\hline F-statistic & $4.38^{\star \star \star}$ & $3.71^{\star \star \star}$ & $2.21^{*}$ \\
\hline Prob > F & 0.0016 & 0.0047 & 0.0606 \\
\hline
\end{tabular}

Note: $t$ - scores for the independent variables are shown in parenthesis. The symbols *,**,*** denote a $10 \%, 5 \%$, and $1 \%$ level of significance, respectively.

Additionally, government size may be measured as the number of government employees located within the state, so the number of state government employees and the number of state and local government employees are used in order to examine the effect of resource 
intensity on government size. In order to be consistent with the previous findings, resource intensity should be positively and significantly related to the number of state government employees and the number of state and local government employees. The results show that the greater the level of resource abundance, the greater the size of government. Again, this is particularly true across point resources indicating that the conclusion of the previous findings are, indeed, robust. Tables 3.7 and 3.8 present the results concerning the relationship between resources and government size as measured by state government employees as a share of the population and state and local government employees as a share of the population, respectively: 
Table 3.7: State Government Employees

\begin{tabular}{|c|c|c|c|}
\hline \multirow[t]{2}{*}{ Dependant Variable: } & \multicolumn{3}{|c|}{ Number of State Government Employees } \\
\hline & (1) & $(2)$ & (3) \\
\hline Constant & $\begin{array}{c}-724.4247 \\
(1.51)\end{array}$ & $\begin{array}{c}-827.079^{\star} \\
(1.77)\end{array}$ & $\begin{array}{c}-1181.148^{\star \star \star} \\
(2.68)\end{array}$ \\
\hline Resource Intensity & $\begin{array}{c}2.6472^{\star} \\
(1.95)\end{array}$ & & \\
\hline Point Resources & & $\begin{array}{c}2.3325^{\star} \\
(1.78)\end{array}$ & \\
\hline Diffuse Resources & & & $\begin{array}{l}1.0602 \\
(0.24)\end{array}$ \\
\hline \# Constitutions & $\begin{array}{c}-2.0961 \\
(0.35)\end{array}$ & $\begin{array}{c}-1.2720 \\
(0.21)\end{array}$ & $\begin{array}{l}1.9110 \\
(0.33)\end{array}$ \\
\hline $\begin{array}{l}\text { Date of Present } \\
\text { Constitution }\end{array}$ & $\begin{array}{l}0.0976 \\
(0.47)\end{array}$ & $\begin{array}{l}0.0696 \\
(0.34)\end{array}$ & $\begin{array}{l}0.0345 \\
(0.16)\end{array}$ \\
\hline $\begin{array}{l}\text { adopted } \\
\text { admendments }\end{array}$ & $\begin{array}{c}-0.0353 \\
(0.48)\end{array}$ & $\begin{array}{c}-0.0426 \\
(0.58)\end{array}$ & $\begin{array}{c}-0.0643 \\
(0.85)\end{array}$ \\
\hline Statehood & $\begin{array}{l}0.4113 \\
(1.45)\end{array}$ & $\begin{array}{c}0.4963^{*} \\
(1.86)\end{array}$ & $\begin{array}{l}0.7242^{\star \star \star} \\
(2.88)\end{array}$ \\
\hline $\begin{array}{l}\text { Share of } \\
\text { Republicans } \\
\text { in House }\end{array}$ & $\begin{array}{c}-1.0415^{\star} \\
(1.81) \\
\end{array}$ & $\begin{array}{c}-0.9070 \\
(1.58) \\
\end{array}$ & $\begin{array}{c}-0.8882 \\
(1.42) \\
\end{array}$ \\
\hline observations & 49 & 49 & 49 \\
\hline $\mathrm{R}^{2}$ & 0.3451 & 0.3359 & 0.2868 \\
\hline F-statistic & $3.69^{\star \star \star}$ & $3.54^{\star \star *}$ & $2.82^{\star *}$ \\
\hline Prob > F & 0.0049 & 0.0063 & 0.0215 \\
\hline
\end{tabular}

Note: $\mathrm{t}$ - scores for the independent variables are shown in parenthesis. The symbols $\star_{, * \star},{ }^{* \star *}$ denote a $10 \%, 5 \%$, and $1 \%$ level of significance, respectively. 
Table 3.8: State and Local Government Employees

\begin{tabular}{|c|c|c|c|}
\hline \multirow[t]{2}{*}{ Dependant Variable: } & \multicolumn{3}{|c|}{$\begin{array}{l}\text { Number of State and Local Government } \\
\text { Employees }\end{array}$} \\
\hline & $(1)$ & (2) & (3) \\
\hline Constant & $\begin{array}{l}1511.88^{\star \star \star} \\
(3.42)\end{array}$ & $\begin{array}{l}1161.391^{* *} \\
(0.16)\end{array}$ & $\begin{array}{l}-89.3263 \\
(0.15)\end{array}$ \\
\hline Resource Intensity & $\begin{array}{l}9.2264^{\star \star \star} \\
(7.40)\end{array}$ & & \\
\hline Point Resources & & $\begin{array}{c}8.1751^{\star \star \star} \\
(6.26)\end{array}$ & \\
\hline Diffuse Resources & & & $\begin{array}{l}3.2204 \\
(0.55)\end{array}$ \\
\hline \# Constitutions & $\begin{array}{c}-1.0821 \\
(0.20)\end{array}$ & $\begin{array}{c}1.7253 \\
(0.29)\end{array}$ & $\begin{array}{c}12.9514 \\
(1.66)\end{array}$ \\
\hline $\begin{array}{l}\text { Date of Present } \\
\text { Constitution }\end{array}$ & $\begin{array}{c}-0.1204 \\
(0.63)\end{array}$ & $\begin{array}{l}-0.2172 \\
(1.06)\end{array}$ & $\begin{array}{c}-0.3443 \\
(1.20)\end{array}$ \\
\hline $\begin{array}{l}\text { adopted } \\
\text { admendments }\end{array}$ & $\begin{array}{l}0.3244 \\
(0.48)\end{array}$ & $\begin{array}{l}0.0073 \\
(1.10)\end{array}$ & $\begin{array}{c}-0.0693 \\
(0.69)\end{array}$ \\
\hline Statehood & $\begin{array}{c}-0.4265 \\
(1.64)\end{array}$ & $\begin{array}{c}-0.1351 \\
(0.51)\end{array}$ & $\begin{array}{c}0.6730 * \\
(2.01)\end{array}$ \\
\hline $\begin{array}{l}\text { Share of } \\
\text { Republicans } \\
\text { in House }\end{array}$ & $\begin{array}{l}0.0839 \\
(0.16)\end{array}$ & $\begin{array}{c}0.5512 \\
(0.97) \\
\end{array}$ & $\begin{array}{c}0.6406 \\
(0.77) \\
\end{array}$ \\
\hline observations & 49 & 49 & 49 \\
\hline $\mathrm{R}^{2}$ & 0.6278 & 0.5570 & 0.1493 \\
\hline F-statistic & $11.81^{\star \star \star}$ & $8.80^{\star \star \star}$ & 1.23 \\
\hline Prob > F & 0.0000 & 0.000 & 0.3113 \\
\hline
\end{tabular}

Note: t- scores for the independent variables are shown in parenthesis. The symbols

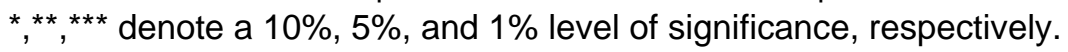




\subsection{Conclusion}

This chapter is the first study to examine the determinants of economic freedom, particularly with regard to government size, across U.S. states. One of the variables consistently found to be negatively correlated with institutional quality is resource intensity, so this paper focuses on the effect of resource intensity on government size, transfers, and subsidies at the state level. The paper concludes that greater resource intensity does lower this component of economic freedom and, thus, lead to an environment that facilitates unproductive entrepreneurship.

This effect is mostly through point resources which are immobile, and therefore, provide a greater incentive for government expropriation and intervention than diffuse resources which are capable of exiting in a classic Tiebout fashion when presented with an undesirable level of government (Tiebout, 1956). This finding is consistent with the literature on the resource curse at the international level and provides more evidence for the importance of the institutional channel through which the resource curse operates. After having established this connection between resource intensity and government size, the next chapter examines how the interaction between institutional quality and resource intensity affect the state's economic development. 


\section{Chapter 4}

\section{The Institutional Curse: Resources, Economic Freedom, and Growth across U.S. States}

\subsection{Introduction}

"There is no curse that can't become a blessing and no blessing that can't become a curse” - adapted from “The Messiah's Handbook: Reminders for the Advanced Soul” by Richard Bach

The inverse relationship between resource abundance and economic growth and development is now commonly referred to as "the resource curse". Sachs and Warner $(1995 ; 2001)$ first examined this correlation and there has since been an extensive amount of scholarship surrounding this seemingly counter-intuitive relationship. An understanding of the exact mechanism through which an abundance of natural resources can negatively impact an economy's development remains illusive. There are several possible explanations concerning the channels through which the resource curse operates. Most of these explanations were appropriately summarized by Sachs and Warner (2001) as the idea that resource abundance will crowd out certain factors that are conducive to growth, and because there is debate about which factors drive growth, there is debate about the true operation of the resource curse.

Included among these numerous possible causes of the resource curse are various institutional explanations. Most central to this paper is the analysis performed by Mehlum, Moene, and Torvik (2006) who found it interesting that some countries with a considerable level of natural resources had very low levels of economic growth, while others exhibited high levels of growth. They examined how the interaction between resources and institutional quality affects growth at the international level and found that those countries with both a high level of institutional quality and a high level of natural 
resources had high levels of growth, while those with low levels of institutional quality and high levels of resource abundance exhibited lower levels of economic growth.

Only recently has the analysis of the resource curse been focused at the state level. This is surprising given that United States data is very conducive to examining the resource curse as all of the states have varying levels of natural resources, but are similar in many ways that resolve issues which are problematic for the international analysis. Some of these problems include inaccurate or inconsistent data, different cultures and military backgrounds, and confounding effects through changes in the exchange rate. Papyrakis and Gerlaugh (2006) were the first to examine the relationship between resource abundance and growth across U.S. states. They found evidence that significant resource endowment negatively affects growth at the state level through the indirect channels of investment, schooling, openness, corruption, and research and development. Dunn (2008) later found that resource abundance can lead to higher levels of rent seeking, which can crowd out productive activity and negatively impact growth. This paper contributes to this limited literature by examining how the interaction between resource abundance and institutional quality affects development across U.S. states.

The next section of this chapter examines the relationship between economic freedom and growth both internationally and at the state level. Section 4.3 provides a review of the various potential explanations for the traditionally negative relationship between resource abundance and growth at the international level. Section 4.4 extends this analysis to the state level by looking at the recent literature on the resource curse in the United States. Section 4.5 provides a description of the data used to empirically 
examine the effect of resource abundance and economic freedom on growth across states.

Section 4.6 presents the empirical model and its results. The final section concludes.

\subsection{Economic Freedom and Growth}

The connection between institutional quality and growth has been well established at both the international and state level. High quality institutions are those that provide secure property rights, free trade, a sound legal environment, and a good monetary system consistent with low inflation. Low quality institutions are those that excessively interfere in the market by placing restrictions on free trade, costly regulations on the labor market, and a lack of property rights which inhibits production and innovation. The Economic Freedom of the World (EFW) Index is a measure of institutional quality that is frequently used in international studies (Gwartney and Lawson, 2002). It is a composite score that judges institutional quality by measuring freedom over 5 different areas: government size, legal structure and security of property rights, access to sound money, freedom to exchange with foreigners, and regulation of credit labor and business. The Economic Freedom of the World index has been used to show that economic freedom is an important component in determining why some countries are growing at faster rates than others. It is consistently found that those countries with more economic freedom exhibit higher growth levels and a higher standard living.

Easton and Walker (1997) used the EFW index to show the importance of economic freedom in examining China and other communist-era countries. They concluded that if these communist-era countries were to engage in more economically free policies then it is likely that they would see remarkable levels of growth resulting in 
a much higher standard of living (Easton and Walker, 1997). Powell (2003) provided evidence that economic freedom was a critical component in Ireland's impressive recent growth record. In fact, he concluded that Ireland's growth was highest when the country adopted policies that lead to its highest economic freedom scores. Research by Cole (2003; 2005) and Gwartney and Lawson (2002) demonstrate a general positive relationship between economic freedom and growth across several different empirical specifications, including a neo-classical growth model and a model including geographical variables. While this research explained the direct correlation between freemarket policies and growth, it did not establish the causal direction between the two variables. However, Dawson (2002) did examine this causal relationship and concluded that the level of economic freedom granger-causes differences in growth among countries.

In addition to establishing this connection at the international level, the relationship between economic freedom and growth has also been well-established at the state level using the Economic Freedom of North America Index. This calculation of economic freedom is slightly different from the world index. Many of the categories that are used in composing the world index do not have enough variance to effectively calculate the differences in economic freedom across states. Many factors such as monetary policy, freedom with regards to foreign currency, private ownership of banks and the right to international exchange are not different across U.S. states. However, state governments still do exhibit significant differences in economic freedom based on the size of the government in the economy, takings and discriminatory taxation, and labor market freedom. 
Karabegovic et al. (2003) and Karabegovich et al. (2008) use the Economic Freedom of North America Index and find a positive relationship between economic freedom and economic growth. Both the level of economic freedom and its growth are directly and significantly related to higher levels of per capita GDP. Kreft and Sobel (1995) provide empirical support that this connection between growth and economic freedom at the state level is the result of the fact that an economically free environment is more conducive to private sector entrepreneurship and it is this entrepreneurship that drives growth. The researchers conclude that those states with more economic freedom also have higher sole proprietor growth rates. Entrepreneurial activity is a key component for growth and development as it results in increased innovation and wealth creating activity. In the absence of this productive entrepreneurship, people are more likely to engage in rent-seeking and other transfer-oriented activities that involve grabbing a piece of the economic pie, rather than making it bigger (Baumol, 1990). Empirical evidence supports Baumol's idea of productive versus unproductive entrepreneurship across the United States (Sobel, 2008). In this study it was shown that institutional quality was positively related to measures of productive entrepreneurship such as venture capital investment per capita, patents per capita, sole proprietor growth rate, total establishment birth rate, and large firm establishment birth rate while being negatively related to measures of unproductive entrepreneurship such as lobbying organizations per capita and a poor score on measures of judicial quality (Sobel, 2008). In addition to higher economic growth, the Economic Freedom of North America Index has been used to show that states with higher levels of economic freedom have lower levels of income inequality (Ashby and Sobel, 2008) and higher migration inflows 
(Ashby, 2007), which indicate that economic freedom is associated with positive outcomes on people's welfare.

\subsection{Resource Abundance and Growth}

It seems counterintuitive that economies which have been seemingly "blessed" with an abundance of natural resources would perform worse than those economies that have no such resources. However, the link between natural resource abundance and low levels of growth and development has been extensively studied and supported at the international level, and this link has also, more recently, been established at the state level. The inverse relationship between resource abundance and economic growth was first examined by Sachs and Warner $(1995 ; 2001)$ who found evidence to support this result at the international level. They concluded that a high value of resource-based exports will lead to lower levels of economic growth; even after controlling for potentially confounding variables such as international trade policies, income inequality, initial income levels, investment, bureaucracy, and terms of trade volatility (Sachs and Warner, 1995). They later found that this relationship holds even when controlling for geography, growth rates, and climates. Resource abundance has even been labeled one of the ten most robust variables when doing an empirical analysis on international economic growth (Sachs and Warner, 2001). Interest in the resource curse exists well beyond just proving its existence. Many studies on this economic anomaly have been centered on how resources affect growth by examining the various channels through which the resource curse operates. 
One common argument on how resource abundance negatively impacts growth is the idea that resource investment projects become prevalent in those countries that have an extensive amount of natural resources (Stevens, 2005). These resource investment projects act as a vacuum and suck up the country's other scarce resources, which can prevent further development within the economy. This potential explanation is handicapped by the fact that it is only relevant in small countries with large investment projects. Another drawback to this explanation is that there is little empirical evidence to support its theoretical predictions (Stevens, 2005).

Another possible explanation for the resource curse is the concept of Dutch disease. This occurs when anything causes a sudden and extreme increase in a nation's wealth which will, in turn, cause the real exchange rate to appreciate (Stevens, 2005). The name Dutch disease was coined after the Netherlands experienced a decline in the manufacturing sector as a result of the discovery of natural gas fields. When an economy experiences an appreciation in the real exchange rate it will import more and export less because its goods and services are more expensive relative to the rest of the world. This decline in exports means that there is less production in the home country which can hurt the nation's industrialization efforts, resulting in lower levels of long-run growth. Dutch disease has been widely examined as a potential cause of the resource curse with conflicting results. Only some of these studies support Dutch disease as the primary mechanism through which the resource curse operates, indicating that it is worthwhile to examine other potential transmission channels (Stevens, 2005).

There has also been a considerable amount of research on the relationship between natural resource abundance and the institutions that develop within an economy. 
The main thread through this institutional explanation of the resource curse is that an abundance of natural resources may cause the government to adopt policies that deter economic growth. There are many ways that resource abundance can lead to institutional decline. One such method is that resource abundance will cause the population to have greater expectations that will, in turn, put pressure on the government, resulting in hasty policies that negatively impact the economy (Stevens, 2005). Natural resource abundance may also cause the government to channel investment away from other profitable sectors, engage in poor industrial policy, and establish subsidies and transfers while restricting trade (Stevens, 2005).

Resource abundance has also been shown to be related to corruption and rent seeking, which are more prevalent in economies with poor institutional quality, and it is through these channels that resources negatively affect growth. Leite and Weidmann (1999) provide both theoretical and empirical evidence to support that natural resources will affect an economy's growth through the indirect channels of corruption and rentseeking. This was especially true in less developed countries, whose institutions may be weaker and less adaptable.

Isham, Woolcock, Pritchett, and Busby (2005) further examine the relationship between rent-seeking and natural resource abundance by distinguishing between two types of resources. They define point resources as those that can only be taken from a narrow geographic or economic area (these include resources like fuels and minerals). Diffuse resources are comprised of food and agricultural products. They conclude that while rent-seeking is related to resource abundance, it is much more likely to occur when a nation is primarily exporting point resources as opposed to diffuse resources. Bulte, 
Damania, and Deacon (2005) conclude that point resources are more likely to lead to poor economic indicators through the indirect channel of institutions. Point resources are more susceptible to corruption, rent-seeking and are more likely to be affected by poor institutional quality because they are immobile and, therefore, cannot leave in response to the negative impact of such factors. Alternatively, diffuse resources can be more easily moved to other jurisdictions in response to bad institutions and this mobility can serve as a way to constrain government and enforce better public policy (Tiebout, 1956).

Papyrakis and Gerlaugh (2004) also examined the relationship between natural resources and growth through the indirect channel of corruption in addition to other indirect channels such as investment, openness, education, and terms of trade. They analyze a sample of 39 countries to conclude that natural resource abundance negatively impacts an economy through these indirect channels. Particularly, an abundance of natural resources will lead to higher levels of corruption, lower investment, deteriorating terms of trade, more protectionist measures, and lower levels of education (Papyrakis and Gerlaugh, 2004). This is consistent with the idea that natural resource abundance leads to increased income that will cause a nation to become slothful and less vigilant when it comes to economic policies and institutional quality (Sachs and Warner, 1995).

Economies will rest on their resource abundance and neglect to invest, innovate, and otherwise work toward long-run growth. Further, an abundance of natural resources reduces the returns to investment and education as an economy can immediately succeed by living off of their natural resources in the short run (Gylfason, 2001). This reduction in investment and education will have adverse effects on the economy's ability to succeed in the long-run. 
The research that examines the connection between resource abundance and institutional quality has largely been aimed at providing evidence to support the idea that resource abundance leads to poor institutional quality and this is how resources negatively impact growth. Easterly and Levine (2003) provided an international analysis that crop production and geography in general only affects development through its impact on institutional quality and that there is no evidence that tropical climates, germs, and crops affect countries development directly other than through its impact on institutional quality (Easterly and Levine, 2003).

In an international analysis, Mehlum, Moene, and Torvik (2006) provide both theoretical and empirical evidence that the resource curse only exists in countries with poor institutional quality. ${ }^{10}$ They note that not all resource abundant countries have low levels of economic growth, and in some cases, resource abundance can be a blessing, rather than a curse. For example, Botswana is very rich in natural resources (particularly diamonds, a point resource) and, yet, still exhibits significant growth. Upon further investigation, the researchers find that among African countries, Botswana has the best score on the Grongingen Corruption Perception Index used for measuring institutional quality (Mehlum, Moene, and Torvik, 2006). Similarly, Norway has a considerable amount of both point (oil and natural gas) and diffuse (timber, fish) resources and is considered one of the least corrupt countries in the world. As a result, Norway's growth has been phenomenal, going from one of the poorest countries in Europe in the 1900's to currently one of the richest. The experiences of these nations were very different from that of Nigeria, Mexico, and Venezuela who suffered from low economic growth after

\footnotetext{
${ }^{10}$ For a description of the theoretical model, please see their paper "Institutions and the Resource Curse" by Mehlum, Moene, and Torvik (2006)
} 
the discovery of oil within the respective nations. This is largely due to the fact that these countries have poor institutions that consist of expropriative governments (Lane and Tornell 1996; Tornell and Lane, 1999).

In their paper, the researchers classify institutions as either grabber-friendly or producer-friendly as measured by an institutional quality index that consists of the nonweighted average of five indexes, which include: a rule of law index, a corruption of government index, a risk of expropriation index, a government repudiation of contracts index, and a bureaucratic quality index (Mehlum, Moene, and Torvik, 2006). They use the typical measure of resource abundance, which is the share of primary exports in GDP, and their measure for institutional quality to create an interaction term in order to look at the combined effect of resources and institutions on economic development. They found this interaction term to be positive and significant; indicating that the resource curse only exists in those countries with poor "grabber-friendly" institutions. In those countries with good institutions, resource abundance can enhance growth. When looked at this way, the nations that supposedly suffer from a resource curse may actually be suffering from an institutional curse. The next section will discuss the analysis of the resource curse at the state level.

\subsection{The Resource Curse in the United States}

Most of the research performed on the connection between resource abundance and growth is performed using international data and only recently has any work been performed at the state level. This is somewhat surprising given that the United States is an ideal setting for analyzing the relationship between resources and growth. U.S. data 
has several advantages over international data when examining the resource curse. Different states, like different countries, have various levels of natural resources as well as different growth patterns and different levels of institutional quality (with regard to state governments). However, unlike different countries, all U.S. states use the same currency so it is unlikely that the exportation of resources from any one state is going to lead to volatility in the exchange rate and a reduction in terms of trade that lead to the resource curse. This is significant, as Sachs and Warner (2001) refuted the idea that an abundance of natural resources caused poor institutional quality and thought that Dutch disease was the more accurate explanation. They note that, while this economic phenomenon is not easily explained, there is evidence that resource abundant countries tend to be high priced economies that will be unable to take advantage of export-oriented growth (Sachs and Warner, 2001). When conducting a cross-state analysis, the likelihood that this is the correct explanation for the resource curse is severely reduced.

Another advantage that U.S. data has over international data is that U.S. states are less likely to differ with regards to culture and military history then different countries. For the most part, U.S. states have had more similar experiences with their involvement in wars than different countries so it is unlikely that differences in growth across states is determined by some aspect of military history, which would be difficult to formally measure and use in an econometric model. This argument can also be extended to the various cultures found within each state. While it is true that there are very real cultural differences between West Virginia and California for example, or Texas and most other states, these differences are likely not as significant as the differences between Nigeria and Norway. Again, these cultural variables are difficult to measure and incorporate into 
a model so using U.S. data is a good way to reduce them and keep them from biasing the results. Finally, U.S. data are more consistent in that the variables tend to be measured in the same way over the same time period and are available for all states whereas international data is more subject to inaccurate or missing records and measurement problems.

Papyrakis and Gerlaugh (2006) provide the first regional study of the resource curse by extending their international work on the indirect transmission channels of resource abundance to the United States. The authors find that natural resource abundance is negatively correlated with growth across states because resource abundance decreases investment, schooling, openness, and expenditure on research and development, while increasing corruption. The idea that natural resources crowd out investment and the development of human capital, while being negatively related to institutional quality, holds at the regional level as well. Recent research has also provided both theoretical and empirical support for the idea that resource abundance will lead to a higher level of rent seeking through the use of the severance tax across the United States (Dunn, 2008). The author finds that this holds for both point and diffuse resources. The idea that resource abundance can hurt growth through increased rentseeking that crowds out productive activity is consistent with Baumol's theory of productive versus unproductive entrepreneurship (Baumol, 1990).

This chapter extends the limited research of the resource curse across U.S. states by analyzing the effect of institutional quality on the relationship between resource abundance and growth. In particular, this chapter attempts to show that the result found by Mehlum, Moene, and Torvik (2006) in which the resource curse only exists in those 
countries with grabber-friendly institutions extends to U.S. states by adapting their interaction term to the growth model presented in Papyrakis and Gerlaugh's (2006) original regional analysis of the connection between resource abundance and growth. The next section will examine the data used to empirically test the connection between resources, institutions, and growth.

\subsection{Data}

This paper will use an interaction term similar to that created by Mehlum, Moene, and Torvik (2006) in order to analyze the connection between resources, institutions and growth across U.S. states. The Economic Freedom of North America Index (EFNA) will serve as the measure of institutional quality. As noted earlier, the EFNA has been used as a way to measure institutional differences across states in many other studies and has been shown to be related to growth and welfare factors across states. This index is comprised of three categories, all of which are calculated at the state or province level (Karabegovic et. all, 2003; Karabegovic et. all, 2008). The first area includes measures for the size of the government in the economy as well as subsidies and transfers. Contained within the calculation of this score are the general consumption expenditures by the government as a percentage of Gross State Product (GSP). This represents how involved the state government is within the economy. A heavy state involvement beyond the minimal productive and protective functions of the government could result in less growth through a crowding out of the private sector. Subsidies and transfers involve the removal or dissolution of property in an effort to redistribute rather than create wealth. 
This type of activity is similar to that of what Mehlum, Moene, and Torvik (2006) labeled grabber-friendly institutions.

Area 2 includes takings and discriminatory taxation. This consists of total government revenue as a percentage of GSP, the top marginal tax rate and the income threshold with which it applies, indirect taxes as a percentage of GSP, and sales taxes collected as a percentage of GSP. A higher tax burden leads to increased deadweight loss and reduced economic efficiency as well as restricting private choice. This is especially true when these taxes have a discriminatory impact and are not paid in proportion to the benefits received from the use of the tax. Thus, a higher tax rate reduces freedom and is represented by a lower score in this area of calculation for the EFNA (Karabegovic et. all, 2003; Karabegovic et. all, 2008).

Area 3 represents labor market freedom. This includes minimum wage legislation, government employment as a percentage of total state employment, and occupational licensing. A high minimum wage limits the ability of employers and employees to formulate contracts. This component is measured as the annual income of minimum wage workers divided by per capita GSP (per capita GSP is used as a proxy for productivity). The higher minimum wage as a percentage of productivity is, the more it restricts the ability of workers and firms to reach agreements concerning employment and, thus, reduces freedom. A high percentage of government employment will also reduce economic freedom as it indicates that the government is producing goods and services beyond the minimal levels necessary for efficiency. Finally, a higher number of regulated occupations will reduce the mobility of labor as well as restrict entry into the market and will, therefore reduce economic freedom and be characterized by a lower 
score in this component of the index (Karabegovic et. all, 2003; Karabegovic et. all, 2008).

These three areas are measured on a scale of 1 to 10 with 10 representing being the most free and 1 being the least free. The three areas are then equally weighted and averaged together in order to get the total freedom score for the state, also measured on a scale from 1 to 10 . Those states with a higher EFNA score represent those institutions which are producer-friendly as labeled by Mehlum, Moene, and Torvik (2006), while those with a lower economic freedom score represent low quality or grabber-friendly institutions. The North American Economic Freedom Index is calculated both with the inclusion of federal government spending for U.S. states and without it. The primary focus of this paper is the effect of the relationship between the state institutions and resource abundance on development, so the analysis will focus only on the measure that excludes the involvement of the federal government. While research at the international level, such as that conducted by Mehlum, Moene, and Torvik (2006), combines various indexes to form a measure of institutional quality, the Economic Freedom of North America Index by itself provides an adequate measure of institutional quality across U.S. states. This is because U.S. state institutions still operate under an over-arching federal government that applies the same macroeconomic policies and rule of law across all states. Therefore, there is little variation in these areas across states and no need for additional measures of institutional quality.

The measure of Resource Intensity used in this study is comprised of the total share of agriculture, forestry, fishing, and mining as a percentage of the economy (or in this case, GSP). This measure of resource intensity is more concerned with the reliance 
on natural resources within the economy rather than the actual amount of resources within the state and, is therefore, an imperfect measure of resource abundance. Also, all states have experienced a general decrease in resource intensity over the time period examined within this study. Nonetheless, it is the most common measure for resource intensity in both the international and regional literature that analyzes the resource curse and it is the measure used by Mehlum, Moene, and Torvik (2006) of which this analysis is based, and by Papyrakis and Gerlaugh (2006) and Dunn (2008) in their papers that examine the resource curse across the United States.

This study will use a growth model adapted from the one used by Papyrakis and Gerlaugh (2006) in the first regional analysis of the resource curse. Their study analyzes the effect of resource intensity as measured in 1986 on the effect of growth from 1986 to 2000. It is common to include this lag when measuring the effect of resource intensity on growth because resources in one year are not expected to affect the development of the economy in that same year, rather it is expected to influence the development of the economy in subsequent years. This study takes the same measure of resource intensity and multiplies it by the EFNA score (without the inclusion of federal spending) for 1986 to develop an interaction term similar to the one used by Mehlum, Moene, and Torvik (2006). This interaction term is used to study the effect of resource intensity, operating through institutional channels, on an economy's development over the years 1986$2005^{11}$. The dependent variable, Growth, is the average annual growth rate in real percapita GSP between 1986 and 2005 measured as $(\ln (Y 2005 / Y 1986) / 19)$ x 100\%.

\footnotetext{
${ }^{11} \mathrm{~A}$ list of the variables used and their description is located in appendix 4A. The names of the variables appear in italics throughout the text.
} 
As control variables, this paper follows the model used by Papyrakis and Gerlaugh (2006) with some additional controls that have been shown to be related to growth. In their analysis, Papyrakis and Gerlaugh (2006) control for conditional convergence by including Initial Income which is measure as the log of GSP per capita in 1986. The same control is incorporated in this study. They also include a measure for Investment that involves the share of industrial machinery production in GSP for the year 1986. Empirical evidence shows that machinery production is more strongly associated with productivity growth then other investment components when measured across nations (De Long and Summers, 1991). They also included an educational variable known as Schooling that consists of the contributions of educational services as a share of GSP in 1986. This variable is supposed to serve as a proxy for investments in human knowledge which is expected to contribute positively to economic growth.

They next include a variable for Openness which is measured differently when comparing the openness of one U.S. state to the next as compared to looking at this difference across countries. They define openness as the ratio of net international migration for the 1990-1999 period relative to the population of the state in 1990 for each state. A more open economy will receive more foreigners compared to a relatively closed economy and it is likely that these in-coming people will carry a certain amount of human capital with them, so it is expected that being a more open economy will contribute positively to economic growth. They also included a measure for research and development $(R \& D)$, defined as the share of research and development in GSP for 1987, which serves as a measure for innovative ability within the respective economies. It is expected that those states who contribute more to R\&D and thus enhance their innovative 
ability will also expect to see higher growth rates (Papyrakis and Gerlaugh, 2006). In order to stay consistent with this initial analysis of the resource curse across U.S. states, this study also incorporates these same variables of Initial Income, Investment, Schooling, Openness, and $R \& D$ as controls into the model.

There is research to suggest that some other controls should be included in this growth model. Gallup, Mellinger, and Sachs (1998) looked at the connection between geography and international economic development, and noted some stylized effects regarding certain geographic variables and growth. Globally, they found that land-locked countries tend to be more poor than coastal economies and that there is a weakly positive relationship between population density and income. They have also noted that nearly all countries with tropical climates are poor and that income grows as one goes from tropical climates to countries with more temperate weather. Their empirical findings suggest that coastal countries and those with a more temperate climate do perform better than landlocked countries and economies with more tropical climates. Also, population density is positively related to growth, but only in coastal areas.

There are several explanations for why these different geographic variables matter in development. Landlocked countries tend to do worse in terms of development than other countries because of their lack of access to waterways which can reduce transaction costs in developing an economy's infrastructure and make migration easier. For this reason, this study includes a dummy variable (Coastal) equal to 1 if the state has any coast line at all or equal to zero if the state is landlocked. It would be expected that having a coast would have a positive impact on growth High population densities may be favorable for development because of increasing returns to scale in infrastructure 
networks and increased specialization and division of labor. In order to incorporate this into the model, a variable Pop_Density, which is measured as population divided by square mile for each state in 1986, is included. This variable is also expected to have a positive impact on development. Tropical climates may have had trouble developing because the weather yields a higher prevalence of certain diseases and lower agricultural output. In order to measure the effect of tropical climates on growth the average number of annual heating degree days from 1971 to 2000 is included into the model as a measure for Climate. The higher the number of heating days the more temperate the climate and so it is expected to be positively correlated with growth. Equipped with this discussion of the data, the next section will look at the empirical model and the results it yields.

\subsection{Empirical Model and Results}

The purpose of this study is to examine the affect of the relationship between resource intensity and institutional quality on economic growth. In particular, it aims to see if the international result that only countries with poor institutions suffer from the resource curse examined by Mehlum, Moene, and Torvik (2006) can be found within the United States. Using the North American Economic Freedom Index sub-national composite score as our measure of institutional quality and the standard measure for resource intensity that is consistently used throughout the literature, we can create an interaction term by multiplying these two variables together and, thus, analyze the following model:

$$
\text { Growth }=\mathrm{a}_{0}+\mathrm{b}_{1} \text { EFNA }+\mathrm{b}_{2} \text { Resource_Intensity }+\mathrm{b}_{3} \text { Interaction }+\mathrm{b}_{4} \mathrm{Z}
$$

Where $\mathrm{Z}$ is the list of control variables mentioned in the previous section. Table 4.1 provides the results where regression 1 utilizes equation 1 presented above. 


\section{Table 4.1: Resource Intensity}

\begin{tabular}{|c|c|c|c|}
\hline \multirow[t]{2}{*}{ Dependant Variable: } & \multicolumn{3}{|c|}{$\begin{array}{l}\text { The average annual growth rate in gsp per } \\
\text { capita from 1986-2005 }\end{array}$} \\
\hline & (1) & $(2)$ & (3) \\
\hline Constant & $\begin{array}{l}16.8528^{\star * *} \\
(4.95)\end{array}$ & $\begin{array}{l}11.2775^{\star *} \\
(1.82)\end{array}$ & $\begin{array}{l}18.9003^{\star \star \star} \\
(5.06)\end{array}$ \\
\hline EFNA & $\begin{array}{c}0.1213^{*} \\
(1.74)\end{array}$ & $\begin{array}{c}0.1084 \\
(1.30)\end{array}$ & $\begin{array}{l}0.1137 \\
(1.27)\end{array}$ \\
\hline Resource Intensity & $\begin{array}{l}-0.1150^{* *} \\
(2.14)\end{array}$ & $\begin{array}{c}-0.1568^{*} \\
(1.78)\end{array}$ & $\begin{array}{l}-0.1573^{\star *} \\
(2.26)\end{array}$ \\
\hline Interaction & $\begin{array}{l}0.0185^{\star *} \\
(2.49)\end{array}$ & $\begin{array}{c}0.0229^{*} \\
(1.95)\end{array}$ & $\begin{array}{c}0.0229 * * \\
(2.44)\end{array}$ \\
\hline Initial Income & $\begin{array}{l}-1.4384^{\star \star \star} \\
(4.00)\end{array}$ & $\begin{array}{l}-0.8186 \\
(1.20)\end{array}$ & $\begin{array}{l}-1.6228^{\star \star \star} \\
(4.09)\end{array}$ \\
\hline Investment & $\begin{array}{c}-0.0007 \\
(0.02)\end{array}$ & $\begin{array}{c}-0.0509 \\
(0.95)\end{array}$ & $\begin{array}{r}-.0009 \\
(0.03)\end{array}$ \\
\hline Schooling & $\begin{array}{c}0.0429 \\
(0.39)\end{array}$ & $\begin{array}{l}-0.0848 \\
(0.47)\end{array}$ & $\begin{array}{l}-0.0035 \\
(-0.03)\end{array}$ \\
\hline Openness & $\begin{array}{c}7.6747^{\star *} \\
(2.50)\end{array}$ & $\begin{array}{l}0.4993 \\
(0.08)\end{array}$ & $\begin{array}{c}8.4316^{\star *} \\
(2.38)\end{array}$ \\
\hline$R \& D$ & $\begin{array}{c}-0.0316 \\
(1.02)\end{array}$ & & $\begin{array}{l}-0.0373 \\
(1.05)\end{array}$ \\
\hline Coastal & $\begin{array}{c}-0.0460 \\
(0.45)\end{array}$ & $\begin{array}{l}-0.0271 \\
(0.25)\end{array}$ & $\begin{array}{l}-0.0216 \\
(0.20)\end{array}$ \\
\hline Pop Density & $\begin{array}{l}0.0004^{\star \star} \\
(2.19)\end{array}$ & $\begin{array}{c}0.0004^{*} \\
(1.76)\end{array}$ & $\begin{array}{c}0.0004^{\star *} \\
(2.17)\end{array}$ \\
\hline Climate & $\begin{array}{c}0.0001^{\star \star *} \\
(4.10)\end{array}$ & $\begin{array}{c}0.0001^{\star * *} \\
(3.36)\end{array}$ & $\begin{array}{c}0.0001^{\star \star *} \\
(4.17)\end{array}$ \\
\hline observations & 49 & 50 & 49 \\
\hline $\mathrm{R}^{2}$ & 0.6127 & 0.3751 & 0.5740 \\
\hline F-statistic & $4.98^{\star \star \star}$ & $4.60^{* \star *}$ & $4.14^{\star \star \star}$ \\
\hline Prob > F & 0.0001 & 0.0002 & 0.0005 \\
\hline
\end{tabular}

Absolute t-ratios for the independent variables are shown in parenthesis.

The symbols $* * *, * * *$ denote a $10 \%, 5 \%$, and $1 \%$ level of significance, respectively. joint tests are significant. The Huber / White Sandwich estimator of variance was used in every regression to report robust standard errors. 
The results show that economic freedom has a positive and significant effect on growth which is consistent with the past literature on the connection between freedom and growth. Resource intensity is negatively correlated with growth which is consistent with the resource curse hypothesis and the findings by Papyrakis and Gerlaugh (2006). However, the interaction term is both positive and significant which is consistent with the results at the international level found by Mehlum, Moene, and Torvik (2006) regarding the effect of the relationship between resource abundance and institutions on growth. This indicates that the resource curse only exists in states with poor institutions as measured by low scores on the Economic Freedom of North America Index. For those states with higher levels of economic freedom, resource abundance may be conducive to growth.

In order to find out what level of institutional quality as measured by economic freedom is necessary for resources to further enhance growth, one can use equation 1 to take the derivative of growth with respect to resource intensity. Given that the interaction term is equal to the economic freedom score multiplied by resource intensity, we get the following equation:

$$
\text { Growth }=\mathrm{a}_{0}+\mathrm{b}_{1} \text { EFNA }+\mathrm{b}_{2} \text { Resource_Intensity }+\mathrm{b}_{3} \text { Resource_Intensity*EFNA }+\mathrm{b}_{4} \mathrm{Z}
$$

If we take the derivative of growth with respect to resource intensity we get:

$$
\frac{\partial \text { Growth }}{\partial \text { Resource Intensity }}=\mathrm{B}_{2}+\mathrm{B}_{3} \text { EFNA }
$$

where $\mathrm{B}_{2}$ is the coefficient for the resource intensity variable and $\mathrm{B}_{3}$ is the coefficient for the interaction term. By setting this equation equal to zero in order to find out the level of economic freedom in which the effect of resource abundance on growth turns positive we get the following: 


$$
\mathrm{B}_{2}+\mathrm{B}_{3} \mathrm{EFNA}=0
$$

We can then solve for economic freedom by subtracting $\mathrm{B}_{2}$ to the other side and dividing both sides by $\mathrm{B}_{3}$, where we get:

$$
\mathrm{EFNA}=-\mathrm{B}_{2} / \mathrm{B}_{3}
$$

Using the results from Table 4.1 regression 1 we can see that the effect of resources on growth turns positive when economic freedom rises above $6.22($ EFNA $=-(0.1150 /$ $0.0185)=6.22)$. The coefficient of the interaction term indicates that every one point increase in economic freedom will increase the positive effect of resources on growth by 0.0185 percentage points.

In order to analyze this result the eight most resource abundant states are isolated from the rest of the data. Three of these states (Alaska, Montana, and West Virginia) have a level of economic freedom that is below 6.22 points on the 10 point scale, while five of the states (Louisiana, New Mexico, North Dakota, South Dakota, and Wyoming) have an economic freedom level above 6.22 points. The five states with more economic freedom average a growth rate that is $0.84 \%$ points higher than the three states with less economic freedom over the time period from 1986 to 2005 . This is a significant given that the difference between the highest growth rate and the lowest growth rate across all 50 states for this time period was a mere 2.66 percentage points

With regards to the control variables, as expected initial income is negative and significant supporting that convergence is taking place. Schooling has the expected positive sign, but is insignificant. Investment and R\&D both have an unexpected negative sign, but both are insignificant. The variable measuring the openness of the state's economy has the expected positive and significant sign and this variable appears 
to have the greatest economic impact on growth. Those economies that are more open and receive more net international migration relative to their population are experiencing more growth. The coastal variable, which measures whether or not a state has a coast line, has an unexpected negative sign, but is insignificant. The insignificance of the coastal variable may be the result of the plethora of ocean navigable river systems in the United States, an advantage of the U.S. that was highlighted by Gallup, Mellinger, and Sachs (1998). Population density was found to be positive and significant in this case as was the variable measuring climate indicating that those states with more temperate climates and a higher number of people per square mile will experience greater growth. However, the economic impact of these variables is very small. The model itself is significant at the $1 \%$ level $^{12}$.

Only 49 states were included in regression 1 as Delaware was excluded due to data limitations with regards to the research and development variable. Therefore, the variable $R \& D$ was eliminated in order to include Delaware in the analysis and the results are presented in regression 2. Without the inclusion of $R \& D$, the model experiences a significant decline in R-squared as growth is certainly dependent on research and development which serves as a proxy for innovation. The interaction term, which is the main variable of interest, remains positive and significant indicating that the main result of the model, which is that only states with low economic freedom suffer from the resource curse, holds when including all 50 states and excluding research and development as an explanatory variable. The effect of economic freedom remains positive, but loses its significance, while the effect of resource intensity on growth is still

\footnotetext{
${ }^{12}$ Each table consists of 3 regressions. The first regression uses all control variables for 49 states, the second regression eliminates R\&D to include Delaware, and the third regresson uses a five year average where possible.
} 
negative and significant. Among the control variables, the variable for openness loses its significance and the variable for schooling switches signs, but remains insignificant.

Regression 3 measures growth over the same period using a five year average covering the time period from 1986-1991 for the variables EFNA, resource intensity, initial income, investment, schooling, and population density in order to reduce the possibility that an aberration in a single year was driving the results. A new interaction term was also created using these new measures for economic freedom and resource abundance. All other control variables remained the same. The results were largely unchanged. The effect of economic freedom on growth remained positive, but did lose some of its significance and the variable that measures schooling changed signs, but remained insignificant. The interaction term, which remains the variable of interest, is still significant at the $5 \%$ level and the model itself remains significant at the $1 \%$ level. ${ }^{13}$

In order to differentiate between the importance of the effects of point and diffuse resources, Table 4.2 presents the results of the model using only point resources (those resources that are immobile and related to mining).

\footnotetext{
${ }^{13}$ Given that the previous chapter shows a connection between resource endowment and the area 1 score of economic freedom it may be necessary to run an interaction between resource intensity and each of the three areas of economic freedom separately in 3 different regressions in order to determine if the interaction between economic freedom and resources and its effect on development is determined only by its area 1 score. Upon running these regressions, the interaction term between resource intensity and area 1 and the interaction between resource intensity and area 3 are both positive and significant. The interaction between resource intensity and area 2 is positive, but not significant.
} 
Table 4.2: Point Resources

\begin{tabular}{|c|c|c|c|}
\hline Dependant Variable: & \multicolumn{3}{|c|}{$\begin{array}{l}\text { The average annual growth rate in gsp per } \\
\text { capita from 1986-2005 }\end{array}$} \\
\hline Constant & $\begin{array}{l}16.7434^{\star \star \star} \\
(4.95)\end{array}$ & $\begin{array}{c}10.2051 \\
(1.52)\end{array}$ & $\begin{array}{l}17.5845^{\star \star \star} \\
(5.05)\end{array}$ \\
\hline EFNA & $\begin{array}{l}0.1577^{\star *} \\
(2.57)\end{array}$ & $\begin{array}{l}0.1481^{* *} \\
(2.11)\end{array}$ & $\begin{array}{c}0.1481^{*} \\
(2.01)\end{array}$ \\
\hline Point Resources & $\begin{array}{c}-0.1221^{\star *} \\
(2.25)\end{array}$ & $\begin{array}{c}-0.1507^{*} \\
(1.73)\end{array}$ & $\begin{array}{c}-0.1949 \star \star \star \star \\
(2.75)\end{array}$ \\
\hline Interaction2 & $\begin{array}{c}0.0188^{\star *} \\
(2.52)\end{array}$ & $\begin{array}{c}0.0210^{*} \\
(1.82)\end{array}$ & $\begin{array}{l}0.0275^{\star \star *} \\
(2.83)\end{array}$ \\
\hline Initial Income & $\begin{array}{c}-1.4453^{\star \star \star} \\
(4.00)\end{array}$ & $\begin{array}{c}-0.7254 \\
(0.99)\end{array}$ & $\begin{array}{c}-1.5045^{\star \star \star} \\
(4.01)\end{array}$ \\
\hline Investment & $\begin{array}{c}-0.0107 \\
(0.30)\end{array}$ & $\begin{array}{c}-0.0614 \\
(1.16)\end{array}$ & $\begin{array}{c}-0.0124 \\
(0.39)\end{array}$ \\
\hline Schooling & $\begin{array}{l}0.0260 \\
(0.24)\end{array}$ & $\begin{array}{c}-0.0879 \\
(0.53)\end{array}$ & $\begin{array}{c}-0.0247 \\
(0.22)\end{array}$ \\
\hline Openness & $\begin{array}{c}7.6785^{\star \star} \\
(2.44)\end{array}$ & $\begin{array}{c}-0.3482 \\
(0.05)\end{array}$ & $\begin{array}{c}7.5795^{\star \star} \\
(2.16)\end{array}$ \\
\hline$R \& D$ & $\begin{array}{c}-0.0424 \\
(1.26)\end{array}$ & & $\begin{array}{c}-0.0437 \\
(1.16)\end{array}$ \\
\hline Coastal & $\begin{array}{c}-0.0749 \\
(0.69)\end{array}$ & $\begin{array}{c}-0.0583 \\
(0.51)\end{array}$ & $\begin{array}{c}-0.0481 \\
(0.45)\end{array}$ \\
\hline Pop_Density & $\begin{array}{c}0.0004^{\star \star} \\
(2.08)\end{array}$ & $\begin{array}{c}0.0004 \\
(1.67)\end{array}$ & $\begin{array}{c}0.0004^{\star *} \\
(2.19)\end{array}$ \\
\hline Climate & $\begin{array}{c}0.0001^{\star \star \star} \\
(4.07)\end{array}$ & $\begin{array}{c}0.0001^{\star \star \star} \\
(2.73)\end{array}$ & $\begin{array}{c}0.0001^{\star \star \star} \\
(4.08)\end{array}$ \\
\hline observations & 49 & 50 & 49 \\
\hline $\mathrm{R}^{2}$ & 0.5883 & 0.3696 & 0.5849 \\
\hline F-statistic & $4.03^{\star \star \star}$ & $3.91^{\star \star \star}$ & $4.05^{\star \star \star}$ \\
\hline Prob > F & 0.0007 & 0.001 & 0.0006 \\
\hline
\end{tabular}

Absolute t-ratios for the independent variables are shown in parenthesis.

The symbols $*, * *, * * *$ denote a $10 \%, 5 \%$, and $1 \%$ level of significance, respectively. joint tests are significant. The Huber / White Sandwich estimator of variance was used in every regression to report robust standard errors. 
This model is similar to that of equation 1, but only includes mining as a share of GSP rather than all resources. The new interaction (Interaction2) term is formed by multiplying the economic freedom score and this measure for point resource intensity. The results from this analysis are very similar across all three specifications to the results when all resources are used, indicating that most of the effect of the connection between resources and institutions on growth is through point resources. The effect of institutions on growth is still positive and significant, the effect of point resources on growth is still negative and significant, and the interaction term is still positive and significant. There is little change among the significance and impact of the control variables.

Table 4.3 presents the results of the model when only diffuse resources, which include agriculture, forestry and fishing, are incorporated into the model. 
Table 4.3: Diffuse Resources

\begin{tabular}{|c|c|c|c|}
\hline \multirow[t]{2}{*}{ Dependant Variable: } & \multicolumn{3}{|c|}{$\begin{array}{l}\text { The average annual growth rate in gsp per } \\
\text { capita from 1986-2005 }\end{array}$} \\
\hline & (1) & (2) & (3) \\
\hline Constant & $\begin{array}{l}13.1656^{\star \star \star} \\
(3.06)\end{array}$ & $\begin{array}{c}8.4449 \\
(1.31)\end{array}$ & $\begin{array}{l}13.4625^{\star \star \star} \\
(3.28)\end{array}$ \\
\hline EFNA & $\begin{array}{c}0.1801^{\star *} \\
(2.63)\end{array}$ & $\begin{array}{c}0.1881^{* *} \\
(2.52)\end{array}$ & $\begin{array}{c}0.2202^{\star \star \star} \\
(2.77)\end{array}$ \\
\hline Diffuse Resources & $\begin{array}{c}0.0908 \\
(0.55)\end{array}$ & $\begin{array}{c}0.0958 \\
(0.54)\end{array}$ & $\begin{array}{c}0.1958 \\
(1.06)\end{array}$ \\
\hline Interaction3 & $\begin{array}{c}-0.0063 \\
(0.28)\end{array}$ & $\begin{array}{c}-0.0053 \\
(0.22)\end{array}$ & $\begin{array}{c}-0.0205 \\
(0.81)\end{array}$ \\
\hline Initial Income & $\begin{array}{l}-1.08^{\star *} \\
(2.33)\end{array}$ & $\begin{array}{c}-0.5787 \\
(0.84)\end{array}$ & $\begin{array}{c}-1.1327^{\star \star} \\
(2.58)\end{array}$ \\
\hline Investment & $\begin{array}{c}-0.0056 \\
(0.18)\end{array}$ & $\begin{array}{c}-0.0053 \\
(0.22)\end{array}$ & $\begin{array}{l}0.0011 \\
(0.04)\end{array}$ \\
\hline Schooling & $\begin{array}{c}0.1083 \\
(1.03)\end{array}$ & $\begin{array}{c}0.0711 \\
(0.53)\end{array}$ & $\begin{array}{c}0.1220 \\
(1.19)\end{array}$ \\
\hline Openness & $\begin{array}{l}4.824 \\
(1.34)\end{array}$ & $\begin{array}{c}-0.1048 \\
(0.02)\end{array}$ & $\begin{array}{c}5.3772 \\
(1.50)\end{array}$ \\
\hline$R \& D$ & $\begin{array}{c}-0.0124 \\
(0.36)\end{array}$ & & $\begin{array}{c}-0.0169 \\
(0.49)\end{array}$ \\
\hline Coastal & $\begin{array}{c}-0.0766 \\
(0.72)\end{array}$ & $\begin{array}{c}-0.0594 \\
(0.51)\end{array}$ & $\begin{array}{c}-0.0533 \\
(0.51)\end{array}$ \\
\hline Pop_Density & $\begin{array}{c}0.0004^{\star \star} \\
(2.37)\end{array}$ & $\begin{array}{c}0.0005^{*} \\
(2.01)\end{array}$ & $\begin{array}{c}0.0004^{\star *} \\
(2.54)\end{array}$ \\
\hline Climate & $\begin{array}{c}0.0001^{*} \\
(1.75)\end{array}$ & $\begin{array}{c}0.0001 \\
(0.76)\end{array}$ & $\begin{array}{c}0.0001^{*} \\
(1.88)\end{array}$ \\
\hline observations & 49 & 50 & 49 \\
\hline $\mathrm{R}^{2}$ & 0.5761 & 0.3776 & 0.5699 \\
\hline F-statistic & $6.59^{\star \star \star}$ & $7.60^{* \star *}$ & $5.40^{\star \star \star}$ \\
\hline Prob > F & 0.0000 & 0.0000 & 0.0000 \\
\hline
\end{tabular}

Absolute t-ratios for the independent variables are shown in parenthesis.

The symbols *,**,*** denote a $10 \%, 5 \%$, and $1 \%$ level of significance, respectively.

The Huber / White Sandwich estimator of variance was used in every regression to report robust standard errors. 
In this model, a third interaction term (Interaction3) is formed by multiplying the economic freedom score and the measure for diffuse resource intensity, which is the share of agriculture, forestry, and fishing in GSP. These diffuse resources are inherently different from point resources in that they are more mobile and, therefore, can leave in response to unfavorable government. The results are drastically different across all three specifications when isolating the effect of the interaction between diffuse resources and institutions on growth. Both the variable measuring diffuse resources and the interaction term change signs and become insignificant, while the positive effect of economic freedom on growth remains. Intuitively, it makes sense that point resources are the driving force behind the connection between resource intensity and growth as the immobility of these resources makes them more susceptible to government policy. This is consistent with the result found by Bulte, Damania, and Deacon (2005) at the international level.

\subsection{Conclusion}

This chapter analyzes the effect of the relationship between resource intensity and institutional quality on development at the state level. The fact that institutions are an important factor in economic growth has been analyzed and confirmed across multiple studies. The negative relationship between resource abundance and development, known as the resource curse, has also been examined through various international, and more recently, state-wide studies. Various possible causes of this inverse relationship have been examined to find out how resources negatively impact growth and institutions have been studied as a possible source of this correlation. Mehlum, Moene, and Torvik (2006) 
used an interaction term to conclude that the resource curse only reared its ugly head in nations with grabber-friendly institutions, while resources contributed to higher growth in countries with producer-friendly institutions.

Using the methodology applied by Mehlum, Moene, and Torvik (2006) in conjunction with the basic growth model analyzed by Papyrakis and Gerlaugh (2006), who were the first to examine the resource curse across U.S. states, this study concludes that the resources only negatively effect growth in states with poor institutional quality when using the Economic Freedom of North America Index as the measure for institutional quality. This paper also further extends this analysis by showing that this result is largely driven by point resources rather than diffuse resources. This can have important policy implications as it shows that adopting policies more consistent with economic freedom may be even more important for states with a considerable amount of resources, especially if those resources are immobile. By enhancing economic freedom a state can turn the resource curse into a blessing.

The final chapter offers a brief summary and lists some areas of future research before providing some concluding remarks. 


\section{Chapter 5}

\section{Conclusion and Areas of Future Research}

This dissertation has examined the connection between natural resource intensity, institutions, and development across U.S. States. The idea that areas with greater natural resource intensity tend to suffer from low levels of economic development known as the resource curse has been widely examined at the international level. Only recently, despite the many advantageous from doing so, has this connection been analyzed at the sub-national level. In order to add to this limited literature, this dissertation explores the institutional connection between natural resources and growth at the state level.

Chapter two examines the formation of governments with the idea that resources may lead an area to initially have greater wealth which would result in the more rapid formation of expropriative institutions that foster an economic environment that is not consistent with further development. The chapter provides a simple theoretical model that shows that governments will use more extractive tax policies in the presence of immobile point resources due to the inability of these resources to leave when faced with such policies. A case study on the resource rich state of Wyoming reveals a constitution that is written around state government control, taxation, and regulation of the natural resources found within the states. Empirical evidence further demonstrates that state governments will form more quickly in those areas with a higher level of natural resources due to the increased availability of wealth for the taking.

After having established the connection between resource intensity and the formation of expropriative governments, chapter three analyzes the connection between 
resource intensity and the continued growth of these governments. Consistent with both the international literature and the recent sub-national literature, the results of the empirical model indicate that resource abundance is consistent with increased government size and economic interference, which encourages an economic environment consistent with rent-seeking and unproductive entrepreneurship. It is this type of economic environment that slows development. These results are consistent across multiple specification and measures for government size over the years 1986-2005.

Chapter four examines how the interaction between resources and institutions influence economic development. Consistent with the international literature, this study shows that those states with more productive high-quality institutions tend to benefit from having natural resources while it is only those states with low-quality, grabber-friendly institutions that suffer from the resource curse. Those states with high levels of economic freedom, which indicates a government that encourages an economic environment conducive to innovation, research and development, and productive forms of entrepreneurship, will actually experience greater economic growth as a result of natural resource abundance. This indicates that having free market policies consistent with the ideals of capitalism is even more important in places with natural resource abundance so that these areas can avoid the devastating effects of the resource curse.

The research performed in this dissertation has attempted to answer some questions we have about our world, but, in doing so, has created others. For example, a fascinating result has sprouted as a side effect of the examination of the main question of interest when examining the determinants of government size. It is interesting to note that the only political variable that was significant in this analysis was the average share 
of republicans in the house of representatives. Why the political parties of the senate and the governor have less explanatory power in determining the size of government than the political party of the members of the house of representatives is a research question whose answer may enrich the fields of public choice economics and political science.

This dissertation provides an extensive look at the institutional connection through which the resource curse operates at the sub-national level and provides a greater understanding of this seemingly paradoxical economic phenomenon. However, the examination of the resource curse across U.S. states is far from complete. The studies within this dissertation show that low-quality institutions are more likely to form (and form more rapidly), and once formed will grow larger and become more expropriative in states with large amounts of natural resources. However, if a resource intense state can avoid this tendency to develop and expand these unproductive institutions, then a state with high-quality institutions can use resources for further growth and development. The question remains how some states were able to avoid this initial tendency to form poor institutions, and keep governments from growing to unproductive levels in order to benefit from their resource endowment.

One possibility could be that states whose resources were already known and in production at the time the state governments formed are more susceptible to institutions forming around the expropriation of these immobile industries. States whose governments formed before the knowledge of this resource wealth may not be as likely to focus their policies on economic intervention in these resource sectors. Chapter 2, which focuses on the state constitution of Wyoming, a resource intense state whose government formed about 40 years after the discovery of natural resources, provides support for this 
possibility. It could also be possible that those states able to defeat the resource curse just had a more economically enlightened population from which sprouted leaders with the knowledge that economically free policies would result in greater long-term development, and it was with this knowledge that they were able to avoid the temptations of expropriating wealth from natural resources. This knowledge may help further illuminate the answer for those states currently suffering from the resource curse so that they, too, can adopt these free market policies which seems to be the method in which the resource curse is lifted. 


\section{APPENDIX}

\section{Appendix 2A: Variable List}

Statehood: The year in which the state was admitted into the union (The Book of the States).

Purchase: The year in which the territory which later became the respective state was purchased by and/or ceded to the United States. (Data was found at the University of Texas Libraries at http://www.lib.utexas.edu/maps/histus.html)

Non-fuel Minerals: The value as represented in millions of dollars of all minerals unrelated to the production of fuel in the year 2000. A complete list of all minerals included in this measure can be found in Appendix B. (U.S. Census Bureau: Statistical Abstracts of the U.S)

Coast: A dummy variable equal to 1 of the state has coastline that borders an ocean and/or the Gulf of Mexico and equal to zero if the state is landlocked.

Coal: The number of long tons of coal produced in the year 1900 (U.S. Census Bureau: Statistical Abstracts of the U.S). 


\section{Appendix 2B: Non-fuel Minerals}

Alphabetically listed below are all minerals that are contained within the variable labeled non-fuel minerals.

$\begin{array}{llll}\text { Abrasives } & \text { Feldspar } & \text { Mercury } & \text { Soda Ash } \\ \text { Aluminum } & \text { Fluorspar } & \text { Mica } & \text { Sodium Sulfate } \\ \text { Antimony } & \text { Gallium } & \text { Molybdenum } & \text { Stone } \\ \text { Arsenic } & \text { Garnet } & \text { Nickel } & \text { Strontium } \\ \text { Asbestos } & \text { Gemstones } & \text { Nitrogen } & \text { Sulfur } \\ \text { Barite } & \text { Germanium } & \text { Peat } & \text { Talc } \\ \text { Bauxite } & \text { Gold } & \text { Perlite } & \text { Tantalum } \\ \text { Beryllium } & \text { Graphite } & \text { Phosphate Rock } & \text { Tellurium } \\ \text { Bismuth } & \text { Gypsum } & \text { Platinum } & \text { Thallium } \\ \text { Boron } & \text { Hafnium } & \text { Potash } & \text { Thorium } \\ \text { Bromine } & \text { Helium } & \text { Pumice } & \text { Tin } \\ \text { Cadmium } & \text { Indium } & \text { Quartz Crystal } & \text { Titanium } \\ \text { Cement } & \text { Iodine } & \text { Rare Earths } & \text { Tungsten } \\ \text { Cesium } & \text { Iron Ore } & \text { Rhenium } & \text { Vanadium } \\ \text { Chromium } & \text { Iron and Steel } & \text { Rubidium } & \text { Vermiculite } \\ \text { Clays } & \text { Kyanite } & \text { Salt } & \text { Yttrium } \\ \text { Cobalt } & \text { Lead } & \text { Sand and Gravel } & \text { Zinc } \\ \text { Columbium } & \text { Lime } & \text { Scandium } & \text { Zirconium } \\ \text { Copper } & \text { Lithium } & \text { Selenium } & \\ \text { Diamond } & \text { Magnesium } & \text { Silicon } & \\ \text { Diatomite } & \text { Manganese } & \text { Silver } & \end{array}$

Source: U.S. Geological Survey, Minerals Yearbook, annual and Mineral Commodities Summaries, annual. See http://minerals.er.usgs.gov/minerals/pubs/mcs/2003/mcs2003.pdf 


\section{Appendix 3A: Description of the Data and its Sources}

Area 1 score: The sub-national score for area 1 using the North American Economic Freedom Index in $2005 .^{14}$

Resource Intensity: The share of the primary sector's production (mining, agriculture, forestry, and fishing) in GSP per state averaged over the years 1986-1990. ${ }^{15}$

Resource Intensity (1986): The share of the primary sector's production (mining, agriculture, forestry, and fishing) in GSP per state in the year $1986 .^{15}$

Point Resources: The share of mining in GSP per state averaged over the years 1986$1990 .{ }^{15}$

Point Resources (1986): The share of mining in GSP per state in the year $1986 .{ }^{15}$

Diffuse resources: The share of agriculture, forestry, and fishing in GSP per state averaged over the years 1986-1990. ${ }^{15}$

Diffuse resources (1986): The share of agriculture, forestry, and fishing in GSP per state in the year $1986 .^{15}$

\# Constitutions: This is the total number of state constitutions for each state. ${ }^{16}$

Date of Present Constitution: this is the year in which the present state constitution is effectively adopted. ${ }^{16}$

\# of adopted amendments: this is the number of amendments that have been adopted to the current state constitution. ${ }^{16}$

Statehood: This is the year that each state was admitted into the union. ${ }^{16}$

Share of Republicans in House: this is the number of republican members of the state house of representatives divided by the total number of members in the state house of representatives averaged over the years 1986-2005, where the data is available, for each state. $^{16}$

Share of Republicans in Senate: this is the number of republican members of the state senate divided by the total number of members in the state senate averaged over the years 1986-2005, where the data is available, for each state. ${ }^{16}$

Governor: For each year that the governor is a republican, a value of 1 is recorded, otherwise it is 0 . These numbers are then averaged over the years 1986-2005. ${ }^{16}$

\footnotetext{
14 this data can be found at http://www.freetheworld.com/

15 this data can be found at the Bureau of Economic Analysis (BEA, 2007)

16 This data, when available, is from various editions of the Book of the States
} 
Area 1A score: Government general consumption expenditures as a share of GSP using the North American Economic Freedom Index in 2005. ${ }^{14}$

Number of State Government Employees: the number of employees per 10,000 people in the state population who work for the state government in each respective state in $2005 .^{17}$

Number of State and Local Government Employees: the number of employees per 10,000 people in the state population who work for the state government or local government in each respective state in $2005 .^{17}$

\footnotetext{
${ }^{17}$ This data can be found at the U.S. Census Bureau
} 


\section{Appendix 4A: Description of the Data and its Sources}

Growth: Growth is equal to $\left(\ln \left(\mathrm{Y}_{2005} / \mathrm{Y}_{1986}\right) / 19\right) \times 100 \%$. This is the average annual growth rate in per capita GSP between 1986-2005. ${ }^{18}$

EFNA: ${ }^{19}$ The sub-national composite score of the economic freedom index in $1986 .{ }^{19}$

Resource Intensity: ${ }^{19}$ The share of the primary sector's production (mining, agriculture, forestry, and fishing) in GSP per state in $1986 .^{18}$

Point Resources: ${ }^{19}$ The share of mining in GSP per state in $1986 .{ }^{18}$

Diffuse Resources: ${ }^{19}$ The share of agriculture, forestry, and fishing in GSP per state in 1986.

Interaction: this is the interaction term between the various measures of resources and economic freedom used in the paper. For example, in regression 1 it is measured as Resource_Intensity x EFNA.

Initial Income: ${ }^{19}$ The log of real GSP per capita in $1986 .^{18}$

Investment: ${ }^{19}$ The share of industrial machinery production in GSP in $1986 .{ }^{18}$

Schooling: ${ }^{19}$ The contribution of educational services in GSP in $1986 .^{18}$

$R \& D$ : The share of Research and Development in GSP for $1987 .^{20}$

Openness: Net international migration from 1990-1999 divided by the population in 1990 for each state. ${ }^{21}$

Coastal: A dummy variable equal to 1 if the state has any coast line or equal to zero if the state is landlocked.

Pop Density: ${ }^{19}$ The population divided by number of square miles in $1986 .{ }^{21}$

Climate: The average number of annual heating degree days from 1971 to $2000 .^{22}$

\footnotetext{
${ }^{18}$ This data can be found at the Burea of Economic Analysis (BEA, 2007)

${ }^{19}$ For the specifications indicated in the paper (regressions 3,6, and 9) these variables were calculated as stated and then averaged over the time period for 1986-2005.

${ }^{20}$ This data can be found at the National Science Foundation (NSF, 2003)

${ }^{21}$ This was calculated using data available from the U.S. Census Bureau

${ }^{22}$ This data can be found within the Historical Climatography Series No. 5-1 from the Department of Commerce
} 


\section{REFERENCES}

Ashby, Nathan J, 2007. Economic Freedom and Migration Flows between U.S. States. Southern Economic Journal, 73(3), 677-697.

Ashby, Nathan J. and Sobel, Russell S., 2008. Income Inequality and Economic Freedom in the U.S. States. Public Choice, 134: 329-346

Bach, Richard, 2004. Messiah's Handbook: Reminders for the Advanced Soul. Hampton Roads Publishing Company, Inc., VA.

Baumol, William J, 1990. Entrepreneurship: Productive, Unproductive, and Destructive. The Journal of Political Economy, 98(5), 893-921.

Buchanan, James M., 1990. The Domain of Constitutional Economics. Constitutional Political Economy, no. 1 pg.1-1.

Bulte Erwin H., Richard Damania, \& Robert T. Deacon, 2005. Resource Intensity, Institutions, and Development. World Development, 33(7), 1029-1044.

Cole, Julio, 2003. The Contribution of Economic Freedom to World Economic Growth, 1980-99. Cato Journal. Vol. 23, 189-198.

Cole, Julio, 2005. Economic Freedom and World Economic Growth: Evidence and Implications. Revista latinoamerican de Desarollo Economico. No. 5, 101-123.

Council of State Governments. The Book of the States, various editions. Lexington Kentucky.

Cullis, John and Jones, Phillip, 1998. Public Finance and Public Choice. Oxford University Press. pg. 357-371.

Dawson, John, 2002. Causality in the Freedom-Growth Relationship. European Journal of Political Economy, Vol. 19, 479-495

De Long, B.J.. and Summers, L. H., 1991. Equipment, Investment, and Economic Growth. Quarterly Journal of Economics, 106, 445-502

Dunn, Leslie, 2008. The Resource Curse in U.S. States: A Rent-Seeking Model. Working Paper

Easterly, William and Levine, Ross 2003. Tropics, Germs, and Crops: How Endowments Influence Economic Development. Journal of Monetary Economics. 50, 3-39

Easton, Stephen and Walker, Michael 1997. Income, Growth, and Economic Freedom. American Economic Review. Vol. 87 No. 2, 328-332

Gylfason, Thorvaldur, 2001. Natural Resources, Education, and Economic Development. European Economic Review, 45, 847-859.

Gallup, John L., Mellinger, Andrew D., and Sachs, Jeffrey D. 1998. Geography and Economic Development. National Bureau of Economic Research Working Paper No. 6849.

Gwartney, James and Lawson, Robert, 2002. The Concept and Measurement of Economic Freedom. European Journal of Political Economy. Vol. 19, 405-430

Isham, Jonathan, Michael Woolcock, Lant Pritchett, and Gwen Busby, 2005. The Varieties of Resource Experience: Natural Resource Export Structures and the Political Economy of Economic Growth. The World Bank Economic Review, 19(2), 141-174.

Karabegovic, Amela, McMahon, Fred, Ashby, Nathan, Dowd, Alan, Sobel, Russel. Economic Freedom of North America 2008 Annual Report. The Fraser Institute, 2008. 
Karabegovic, Amela, Samida, Dexter, Schlegel, Chris, and McMahon, Fred, 2003. North American Economic Freedom: An Index of 10 Canadian Provinces and 50 U.S. States. European Journal of Political Economy. Vol. 19 (2003) 431-452.

Kreft, Stephen F. and Sobel, Russell S., 2005. Public Policy, Entrepreneurship, and Economic Freedom. Cato Journal, Vol. 25, No. 3.

Lane, P. R. and Tornell, A. (1996). Power, Growth and the Voracity Effect. Journal of Economic Growth, vol. 1, pp. 213-41.

Larson, T.A. History of Wyoming. Lincoln, NE: University of Nebraska Press, 1999.

Leite, Carlos and Jens Weidmann, 1999. Does Mother Nature Corrupt? Natural Resources, Corruption, and Economic Growth. IMF Working Paper, WP/99/85.

Mehlum, Halvor; Moene, Karl; Torvik, Ragnar. 2006. "Institutions and the Resource Curse." The Economic Journal. V116, n508 (January 2006): 1-20.

Niskanen, W. A., 1968. The Peculiar Economics of Bureaucracy. American Economic Review. Vol. 57 No. 2 pg. 293-321.

Papyrakis, Elissaios and Reyer Gerlagh, 2004. The Resource Curse Hypothesis and its Transmission Channels. Journal of Comparative Economics. V32(1), 181-193.

Papyrakis, Elissaios and Reyer Gerlagh, 2006. Resource-Abundance and Economic Growth in the United States. European Economic Review, 51, 1011-1039.

Peacock, A.T. and Wiseman, J., 1961. The Growth of Public Expenditure in the United Kingdom. London: Allen \& Urwin.

Powell, Benjamin. 2003. Economic Freedom and Growth: The Case of the Celtic Tiger. Cato Journal, 22, 431-448.

Rawls, John A. A Theory of Justice. Cambridge, Massachusetts. Belknap, 1971.

Sachs, Jeffrey D. and Andrew M. Warner, 1995. Natural Resource Abundance and Economic Growth. NBER Working Paper, working paper \# 5398.

Sachs, Jeffrey and Andrew Warner 2001. The Curse of Natural Resources. European Economic Review, 45(4-6): 827-838.

Shearer, Benjamin F. The Uniting States: The Story of Statehood for the Fifty United States. Santa Barbara, CA: University of Nebraska Press, 1999.

Sobel, Russell S. 2008. Testing Baumol: Institutional Quality and the Productivity of Entrepreneurship. Journal of Business Venturing. 23, 641-655

Stevens, Paul. 2005. Resource Impact: Curse or Blessing? A Literature Survey. Journal of Energy and Development. V31, n1 (Autumn 2005): 1-20.

Tiebout, Charles. 2006. "A Pure Theory of Local Government Expenditures." Journal of Political Economy. V64, n5 (October 1956): 416-424.

"Title 97: Wyoming State Constitution." Wyoming Legislative Service Office. Wyoming State Legislature. December 12, 2008 http://legisweb.state.wy.us/

Tornell, A. and Lane, P.R. 1999. The Voracity Effect. American Economic Review, vol. 89 , pp. 22-46. 